African Crop Science Journal by African Crop Science Society is licensed under a Creative Commons Attribution 3.0 Uganda License. Based on a work at www.ajol.info/ and www.bioline.org.br/cs DOI: http://dx.doi.org/10.4314/acsj.v24i4.9

\title{
GENOMIC AND TRANSCRIPTOMIC APPROACHES TOWARDS THE GENETIC IMPROVEMENT OF AN UNDERUTILISED CROPS: THE CASE OF BAMBARA GROUNDNUT
}

\author{
F. $\mathrm{KHAN}^{1}$, R. AZMAN ${ }^{2}$, H.H. CHAI ${ }^{3}$, S. MAYES ${ }^{1,2,3}$ and C. LU ${ }^{1}$ \\ ${ }^{1}$ School of Biosciences, University of Nottingham, UK campus, Nottingham, United Kingdom \\ ${ }^{2}$ Crops For the Future, JalanBroga, 43500 Semenyih, Selangor Darul Ehsan, Malaysia \\ ${ }^{3}$ Biotechnology Research Centre, School of Biosciences, University of Nottingham, Malaysia Campus, \\ JalanBroga, 43500 Semenyih, Selangor Darul Ehsan, Malaysia \\ Corresponding author: Stxfk5@nottingham.ac.uk
}

(Received 19 January, 2016; accepted 16 November, 2016)

\begin{abstract}
With the world population estimated to be nine billion by 2050 , the need to exploit plant genetic diversity in order to increase and diversify global food supply, and minimise the over-reliance for food on a few staple crops is of the utmost importance. Bambara groundnut (Vigna subterranea $(\mathrm{L})$ Verdc.), is underutilised legume indigenous to Africa, rich in carbohydrates, with reasonable amounts of protein. It is known to be drought tolerant, able to grow on marginal lands where other major crops cannot with minimal rainfall $(<700 \mathrm{~mm})$ and chemical inputs. Crop improvement for abiotic stress tolerance and increasing/stabilising yield have been difficult to achieve due to the complex nature of these stresses, and the genotype $\mathrm{x}$ environment interaction $(\mathrm{GxE})$. This review paper highlights how a number of recent technologies and approaches used for major crop research, can be translated into use in research of minor crops, using bambara groundnut as an exemplar species. Using drought tolerance as a trait of interest in this crop, we will demonstrate how limitations can affect genomic approaches for understanding traits in bambara groundnut, and, how genomic and transcriptomic methodologies developed for major crops can be applied to underutilised crops for better understanding of the genetics governing important agronomic traits. Furthermore, such approaches will allow for cross species comparison between major and minor crops, exemplified by bambara groundnut leading to improved research in such crops. This will lead to a better understanding of the role of stress-responsive genes and drought adaptation in this underutilised legume.
\end{abstract}

Key Words: Drought stress, Next Generation Sequencing, Vigna subterranea

\section{RÉSUMÉ}

Avec la population mondiale estimée à neuf milliards de personnes à échéance 2050, il est impérieux d'exploiter la diversité génétique des plantes afin d'accroître et diversifier la production globale en aliments, mais aussi réduire la dépendance à outrance de peu d' aliments de base pour l'alimentation humaine. Le vouandzou (Vigna subterranea $(\mathrm{L})$ Verdc.), est une légumineuse indigène sous utilisée enAfrique, mais qui est riche en amidon, avec une quantité raisonnable de proteine. Il reconnu comme étant resistant à la sécheresse, il est capable de pousser et de réaliser un cycle végétatif et reproducteur parfait dans les zones marginales de basse pluiviométrie $(<700$ $\mathrm{mm}$ ) où d'autres cultures majeures ne peuvent survivre. L'amélioration des cultures pour la tolérance face aux stress abiotiques et l'accroissement et la stabilization des rendements ont été difficiles à réaliser en raison de nature complexe de ces stress et l'influence de l'interaction genotype-environment (GxE). Cette revue de literature montre comment les nombreuses technologies et approaches récentes utilisées par la recherche sur les cultures majeures peuvent adaptées et utilisées dans la recherhe sur les cultures mineures, en se servant du bambara 
groundnut comme espèce modèle. En prenant la tolerance à la sécheresse comme caractère désiré pour cette culture, nous allons démontrer commnents les insuffisances des approches de génomique peuvent empêcher la maîtrise des caractères désirés chez le vouandzou et comment les techniques de génomique et de transcriptomique développées pour les cultures majeures peuvent être appliquées aux cultures sous utilisées afin de mieux comprendre les déterminants génétiques gouvernant les caractères agronomiques. De plus, de telles approaches permettra de comparer les cultures majeures et mineures, avec ici l'exemple du vouandzou qui permettra d'améliorer le niveau de recherche chez de telles cultures. Cela permettra de mieux comprendre le rôle des genes répondant au stress hydrique et l'adaptation à la sécheresse chez cette légumineuse sous utilisée.

Mots Clés: Stress hydrique, séquençage des générations futures, Vigna subterranea

\section{INTRODUCTION}

The dependence of global food security on major crops is a major concern in the future for food supply and also for rural income, as yield gains from these major crops may not be enough to sustain the estimated nine billion people on the planet by 2050 (Godfray et al., 2010). Also, the danger presented by climate change, leading to increased drought, temperature, flooding, and salinisation, along with a predicted increase in pests and diseases, could drastically effect major crops growth and development. There is need to widen the exploitation of the available plant genetic diversity in order to increase food supply and avoid dependence on a limited number of plant species for global food and nutritional security. Underutilised crop could be a solution for more diversified agricultural systems, a rich source to explore novel trait values and additional food sources necessary to address food and nutritional security concerns (Jaenicke and Höschle-Zeledon, 2006; Mayes et al., 2012; Williams and Haq, 2002).

With the availability of technologies, such as Next Generation Sequencing (NGS), it is possible to develop molecular markers for marker assisted selection (MAS) in underutilised crops (Moe et al., 2012). This technology is able to generate significant sequence datasets, and allows indepth comparisons to be made between underutilised crops and their major staple crop cousins (Mayes et al., 2012). For underutilised crops, their low and erratic yields can be due to the lack of genetic improvement and formal breeding programmes which may be hindering their wider cultivation and utilisation (Jain and Gupta, 2013).
Several efforts have been made to conserve the germplasm of major crop species, but a more limited amount of effort has gone into conservation of underutilised crops such as bambara groundnut (Vigna subterranea (L) Verdc.). The Consultative Group for International Agricultural Research (CGIAR) and Global Diversity Crops Trust are organisations whose focus is to develop a sustainability plan in order to ensure germplasm conservation and availability of underutilised crops, as a means to increase crop diversity (Khoury et al., 2010; Anon n.d.). Conserving the genetic resources of underutilised crops exemplified by bambara groundnut, is essential as these crops are sources of livelihood in rural poor communities and its cultivation has a positive impact on farmer welfare (William et al., 2016). However, conservation is only one aspect as without 'conservation into use', no impact is made on the lives of the farmers who could benefit. Ex situ and in situ germplasm conservation, with farmer participatory breeding and, identification of favourable traits, offer a productive solution to conserve and utilise the genetic resources of underutilised species. This approach can then be coupled with trait analysis to identify crops which can (i) survive in extreme conditions (e.g., drought and cold), (ii) have superior nutritional content, (iii) and have the potential to achieve high market value in order to increase their utilisation and consumption, contributing to the global food basket (iv) are acceptable to farmers

This is the first review on bambara groundnut with a specific focus on the genomic/ transcriptomic approaches available to address drought through genetic improvement. This review also highlights how some recent 
technologies and approaches used for major crop research, can be translated into use in research of minor crops, such as bambara groundnut. Previous reviews on genetic improvement of bambara groundnut using resources from major species has focused mainly on the overview breeding objectives and aims (Aliyu et al., 2015) Other reviews published on bambara groundnut focus mainly on (i) conservation and improvement (Heller, 1997); (ii) production (Mkandawire, 2007); (iii) developing the potential of the crop (Azam-Ali et al., 2001); (iv) aspects of the commodity marketing of bambara groundnut (Hillocks et al., 2012); (v) breeding approaches towards the genetic improvement of bambara groundnut and (vi) genetic diversity analysis of bambara groundnut (Aliyu et al., 2016, 2015).

Bambara groundnut profiles. Bambara groundnut is probably one of the most droughttolerant of the major grain legumes and may be found surviving successfully where annual rainfall is below $500 \mathrm{~mm}$ and has an optimum between 900-1000 mm per year (Bamshaiye et al., 2011) although it can grow in wetter conditions as long as the roots are not water-logged. It is cultivated mainly in sub-Saharan Africa, expanding to regions of West Africa, across Central Africa to East Africa and Southern Africa (Mohale et al., 2013).

It is cultivated principally by farmers as a food security culture crop, because of its agronomic values and the ability to produce in soils considered insufficiently fertile for cultivation of other more favoured species such as common beans (Phaseolus vulgaris) and groundnuts (Arachis hypogaea) (Olaleye et al., 2013), although there are markets and there is some early evidence that it could improve household incomes (William et al., 2016)

Bambara groundnut has reasonable protein content (18 to $22 \%)$, high carbohydrate $(65 \%)$ and low levels of fats $(6.5 \%)$, having a composition quite similar to chickpea (Cicer arietinum) and makes it a 'complete food' (Mazahib et al., 2013) (Table 1). The seed commands a relatively high market price in many African countries (Coudert, 1984). In countries such as Malawi, demand for bambara groundnut often exceeds supply (Mkandawire, 2007). Bambara groundnut is considered to be the third most valuable legume in Africa, after cowpea (Vigna unguiculata (L.) Walp.) and groundnut (Murevanhema and Jideani, 2013). It is known to be deficient in sulphur-containing amino acids (Azam-Ali et al., 2001), but rich in lysine, leucine and glutamic acid, which makes a good complement to cerealderived amino acids (Mazahib et al., 2013) (Table 2 ); hence in many African countries, bambara groundnut seeds are often milled and added to wheat flour and used to make a number of baked products (Abdualrahman et al., 2012). Although, correlation between genotypes, seed colour, growing conditions and nutritional analysis has never been attempted. The seed is a useful ingredient in cooking as it can be eaten as a boiled or fried snack, and milled into flour (Goli, 1995). Despite its 'balanced' macronutrient composition, bambara groundnut contains some anti-nutritional factors such as tannins and trypsin inhibitors (Barimalaa and Anoghalu, 1997). A study conducted by Ijarotimi and Ruth (2009) showed that fermentation has significant effects in decreasing the anti-nutritional factors; oxalate, tannic acid, phytic and trypsin.

TABLE 1. Macronutrient status of Bambara groundnut in comparison with some more popular legumes

\begin{tabular}{lcccrrr}
\hline Nutritional values & $\begin{array}{c}\text { Bambara } \\
\text { groundnut }\end{array}$ & Soybean & Phaseolus bean & Cowpea & Faba bean & Chickpea \\
\hline Calories & 390 & 416 & 343 & 333 & 341 & 364 \\
Protein (\%) & 21.8 & 36.5 & 23.8 & 23.6 & 26.1 & 19.3 \\
Carbohydrate (\%) & 61.9 & 30.2 & 59.6 & 60 & 58.3 & 60.6 \\
Fat (\%) & 6.6 & 19.9 & 2.1 & 0.8 & 5.7 & 6 \\
\hline
\end{tabular}

Source: (Hillocks et al., 2012) 
TABLE 2. Amino acid content ( $\mathrm{mg} / 100 \mathrm{gm}$ ) of raw Bambara groundnut

\begin{tabular}{lc}
\hline Amino acid & Raw Bambara groundnut \\
\hline Lysine & 2.8 \\
Histidine & 2.4 \\
Arginine & 4.9 \\
AsparticAcid & 5.6 \\
Threonine & 2.6 \\
GlutamicAcid & 17 \\
Glycine & 3.3 \\
Alanine & 3.9 \\
Cystine & 0.7 \\
Methionine & 2.7 \\
Isoleucine & 3.9 \\
Leucine & 6.9 \\
Tyrosine & 3.4 \\
Phenylalanine & 4.8 \\
\hline
\end{tabular}

*Values are mean of duplicate samples

Source: (Mazahib et al., 2013)

Challenges towards research and development in bambara groundnut. Being classed as an underutilised crop, bambara groundnut faces several challenges towards its research and development. Bambara groundnut is still an underutilised crop mainly because (i) it currently has limited economic potential outside its areas of cultivation (Azam-Ali et al., 2001); (ii) lack of appropriate processing techniques to overcome hard-to-cook effects (Mazahib et al.,2013); (iii) absence of functioning value chains (Hillocks $e t$ al., 2012); (iv) there is very little information and knowledge base on neglected plant species in terms genome information and germplasm collection (Azam-Ali et al., 2001); (vi) biological issues such as photoperiod sensitivity to reproductive development and pod-filling, which effects the geographical range/time of planting and yield stability; and (vii) a lack of mechanisation for crop mechanisation (e.g., seed sowing) as well as machinery for post-harvest (e.g., pod-shelling). Furthermore, bambara groundnut is still grown as landraces and its yield can be unstable and unpredictable at different geographical regions. While being adapted to their current environment, landraces may not contain the optimal combination of traits (Massawe et al., 2005). Development of improved varieties of bambara groundnut, through controlled and coordinated multi-locational breeding programmes, is vital to harness the potential of the crop (Aliyu et al., 2015). The International Institute for Tropical Agriculture (IITA) currently holds the largest ex situ collection, with 2055 accessions (as of January 2015) of bambara groundnut. This crop could be a potential exemplar for other underutilised crops. Breeding/Molecular perspectives. Historically, genomic and molecular genetic analysis has been focused towards major species, but now with the advancement in high-throughput sequencing technologies, such as NGS, and the reduction in their costs and also the availability of bioinformatic tools (Table 3 ), it is becoming possible to transfer information to crops and related-species. With the availability of genomic resources and the completion of reference genome sequences of legume crops, such as Medicago truncatula (Young and Udvardi, 2009), Common bean (Schmutz et al., 2014), Soybean (Glycine max) (Schmutz et al., 2010) and Cowpea (Muñoz-Amatriaín et al., 2016), it is now possible to dissect information and transfer genomic and transcriptomic data to other legume crops such as bambara groundnut. For example, the USEARCH sequence analysis tool can be used for comparing sequences between closely related species (Ward and Moreno-Hagelsieb, 2014), enabling advances in genetic marker development, location of orthologues and decoding of the genetic mechanism and pathways involved in drought tolerance in less studied crops, such as bambara groundnut through genomic and transcriptomic comparative analysis.

\section{Drought stress in bambara groundnut}

Drought stress tolerance mechanisms. Drought stress is one of the major abiotic stresses that inhibits proper plant growth and crop productivity. Drought stress is defined as stress that is caused by inadequate soil moisture to meet the needs of a particular crop at a particular time (National Drought Mitigation Center, n.d.). Drought tolerant plants respond to drought stress via a series of different mechanisms. They are divided into three groups namely (i) drought escape, (ii) drought avoidance, and (iii) drought 
TABLE 3. Bioinformatic tools and databases available for genomic/transcriptomic research

\begin{tabular}{|c|c|c|}
\hline Name & Description & URL/Source \\
\hline \multicolumn{3}{|l|}{ Tools } \\
\hline Genome Workbench & An integrated application for viewing and analyzing sequence data. & http://www.ncbi.nlm.nih.gov/tools/gbench/ \\
\hline MISA & Allows identification and localization of perfect microsatellites & http://pgrc.ipk-gatersleben.de/misa/ \\
\hline Trinity & Tool for RNA-seq de novo assembly & https://github.com/trinityrnaseq/trinityrnaseq/wiki \\
\hline ArrayExpressHTS & R-based pipeline for RNA-seq data analysis & $\begin{array}{l}\text { https://bioconductor.org/packages/devel/bioc/html/ } \\
\text { ArrayExpressHTS.html }\end{array}$ \\
\hline USEARCH & Unique sequence analysis tool & http://drive5.com/usearch/ \\
\hline Assembly to Assembly Comparison (ATAC) & $\begin{array}{l}\text { For comparative mapping between two genome assemblies, or between two different } \\
\text { genomes }\end{array}$ & http://seqanswers.com/wiki/ATAC \\
\hline Atlas-SNP2 & SNP detection tool developed for RNA-seq platforms & https://sourceforge.net/p/atlas2/wiki/Atlas-SNP/ \\
\hline BLAST Ring Image Generator (BRIG) & Used for comparative analysis between large number of genomes & http://brig.sourceforge.net/ \\
\hline EdgeR & $\mathrm{R}$ package for differential expression analysis for RNA-seq data & $\begin{array}{l}\text { https://bioconductor.org/packages/release/bioc/html/ } \\
\text { edgeR.html }\end{array}$ \\
\hline solQTL & Tool for analysis and visualization of quantitative trait loci (QTL). & https://solgenomics.net/search/phenotypes/qtl \\
\hline TriClust & Tool for cross-species analysis of gene regulation & http://www.baskent.edu.tr/ hogul/triclust/ \\
\hline \multicolumn{3}{|l|}{ Databases } \\
\hline ArrayStar & Database that holds collection tools for microarray analysis & http://www.arraystar.com/ \\
\hline Bedtools & Database for comparing large set of genomic features & http://bedtools.readthedocs.io/en/latest/ \\
\hline Bionumerics & $\begin{array}{l}\text { Integrated analysis of all major applications in Bioinformatics: } 1 \mathrm{D} \text { electrophoresis } \\
\text { gels, all kinds of chromatographic and spectrometric profiles, phenotype characters, } \\
\text { microarrays, and sequences }\end{array}$ & http://www.applied-maths.com/bionumerics \\
\hline
\end{tabular}


tolerance. Drought escape is described as the ability of plants to complete their growth cycle and reach maturity before drought-stress develops to damaging levels (Kooyers, 2015). Drought avoidance is demonstrated by crop species, which are able to maintain high water potential in the plant by minimising water loss and maximising water uptake under drought conditions, as seen in Siratro (Macroptiliumatro purpureum), a tropical legume (Ludlow, 1989) and chickpea (Gaur et al., 2008). Mechanisms of avoidance include improved root traits, for greater extraction of soil moisture, decreased stomatal conductance, decreased radiation absorption and decreased leaf area for minimal water loss (Harb et al., 2010). Drought tolerance allows plants to survive through water-use efficiency, i.e., performing all biological, molecular and cellular functions with minimal water. Such mechanisms are seen in a range of leguminous species, including mung bean (Vigna radiata) (Ocampo and Robles, 2000) and pigeon pea (Cajanus cajan) (Subbarao et al., 2000). Plants with drought tolerance mechanisms are able to maintain their cell turgor through osmotic adjustment, which in turn will contribute to maintaining stomatal opening, leaf expansion and photosynthesis throughout the drought period (Collinson et al., 1997). Several studies have reported differential expression of genes under drought stress in major crops (Table 4). Even though a large number of drought-related genes have been identified in plants, their stability of trait expression under different stress conditions is a major concern.

Molecular and physiological effects of drought stress on plants. Drought stress can cause cellular, physiological and morphological changes in the plant, for instance, a reduction in photosynthesis, leaf area and final yield in groundnut (Collino et al., 2001), cowpea (Anyia and Herzog, 2004) and chickpea (Singh, 1991). In pea (Pisum sativum), germination and early seedling growth were reported to be influenced by drought (Okcu et al., 2005). Reduction in the number of grains, grain yield, shoot dry weight and harvest index were observed in wheat ( $T$. dicoccoides) when it was subjected to drought stress (Gupta et al., 2001). Drought stress can affect crop growth at any developmental stage 
TABLE 4. Stress-responsive genes contributing to drought tolerance in plants

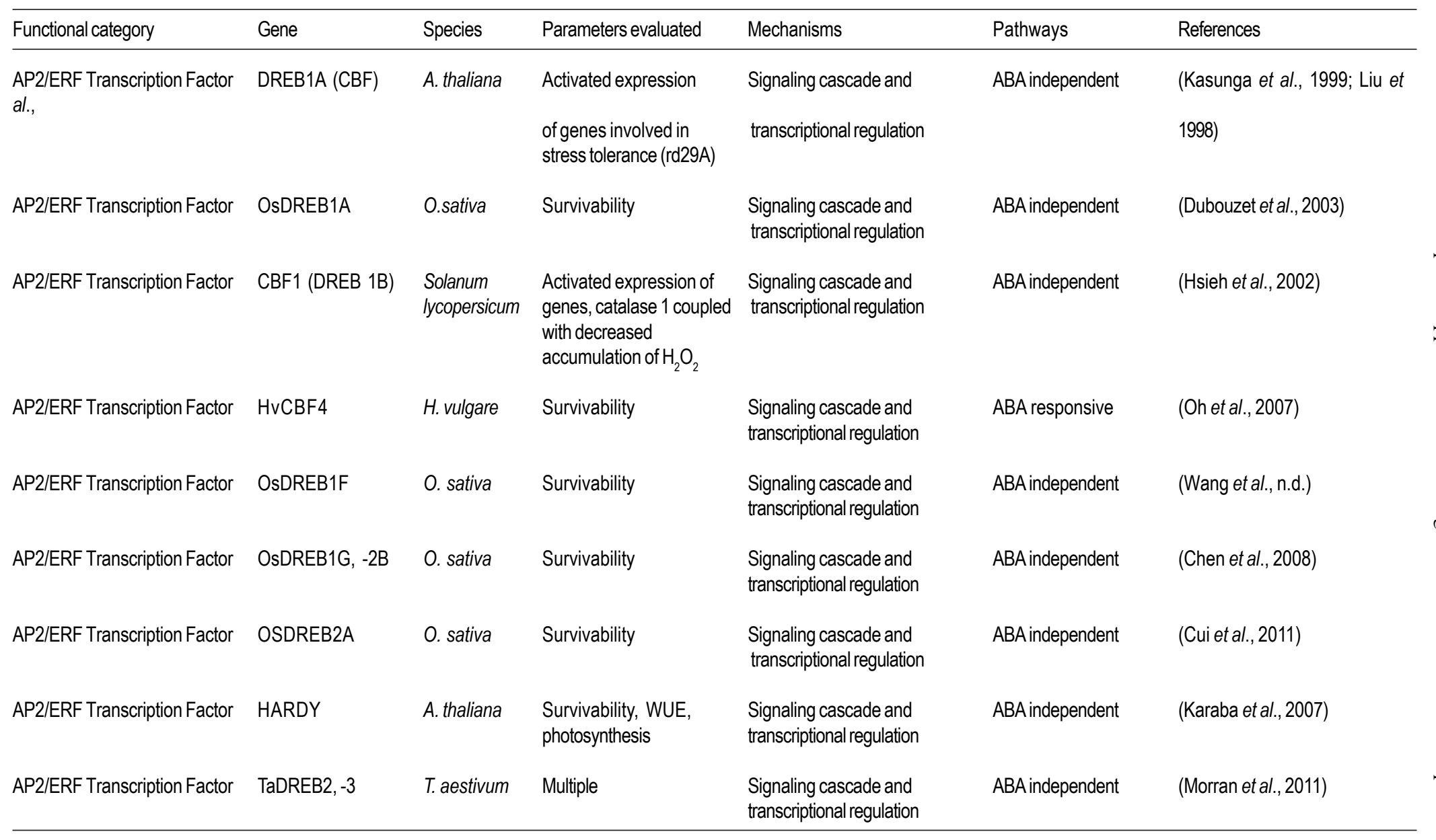




\begin{tabular}{|c|c|c|c|c|c|c|}
\hline Functional category & Gene & Species & Parameters evaluated & Mechanisms & Pathways & References \\
\hline AP2/ERF Transcription Factor & CBF4 & A. thaliana & $\begin{array}{l}\text { Activated expression of } \\
\text { genes involved in stress } \\
\text { tolerance }\end{array}$ & Drought avoidance & ABA responsive & (Haake et al., 2002) \\
\hline bZIP Transcription Factor & OsbZIP23 & O. sativa & Relative yield & $\begin{array}{l}\text { Signaling cascade and } \\
\text { transcriptional regulation }\end{array}$ & ABA responsive & (Xiang et al., 2008) \\
\hline bZIP Transcription Factor & OsbZIP46 & O. sativa & $\begin{array}{l}\text { Survivability, relative } \\
\text { yield }\end{array}$ & $\begin{array}{l}\text { Signaling cascade and } \\
\text { transcriptional regulation }\end{array}$ & ABA responsive & (Tang et al., 2012) \\
\hline bZIP Transcription Factor & OsbZIP72 & O. sativa & Survivability & $\begin{array}{l}\text { Signaling cascade and } \\
\text { transcriptional regulation }\end{array}$ & ABA responsive & (Lu et al., 2008) \\
\hline bZIP Transcription Factor & SIAREB1 & $\begin{array}{l}\text { S. } \\
\text { lycopersicum }\end{array}$ & Multiple & $\begin{array}{l}\text { Signaling cascade and } \\
\text { transcriptional regulation }\end{array}$ & ABA responsive & (Orellana et al., 2010) \\
\hline bZIP Transcription Factor & ABF3/ABF4 & A. thaliana & $\begin{array}{l}\text { Reduced transpiration } \\
\text { and better survival } \\
\text { under drought stress. } \\
\text { Growth arrest }\end{array}$ & $\begin{array}{l}\text { Signaling cascade and } \\
\text { transcriptional regulation }\end{array}$ & ABA responsive & (Kang, 2002) \\
\hline NAC & SNAC1 & O. sativa & $\begin{array}{l}\text { Survivability, seed } \\
\text { setting rate }\end{array}$ & $\begin{array}{l}\text { Drought avoidance, signaling } \\
\text { cascade and transcriptional } \\
\text { regulation }\end{array}$ & ABA responsive & (Hu et al., 2006) \\
\hline NAC & OsNAC9 & O. sativa & Multiple & $\begin{array}{l}\text { Drought avoidance, } \\
\text { signaling cascade and } \\
\text { transcriptional regulation }\end{array}$ & ABA responsive & (Redillas et al., 2012) \\
\hline NAC & OsNAC10 & O. sativa & Multiple & $\begin{array}{l}\text { Drought avoidance, signaling } \\
\text { cascade and transcriptional } \\
\text { regulation }\end{array}$ & ABA responsive & (Jeong et al., 2010) \\
\hline
\end{tabular}


TABLE 4. Contd.

\begin{tabular}{|c|c|c|c|c|c|c|}
\hline Functional category & Gene & Species & Parameters evaluated & Mechanisms & Pathways & References \\
\hline NAC & OsNAC5 & O. sativa & Multiple & $\begin{array}{l}\text { Drought avoidance, signaling } \\
\text { cascade and transcriptional } \\
\text { regulation }\end{array}$ & ABA responsive & (Jeong et al., 2013) \\
\hline NAC & OsNAC6 & O. sativa & Survivability & $\begin{array}{l}\text { Drought avoidance, signaling } \\
\text { cascade and transcriptional } \\
\text { regulation }\end{array}$ & ABA responsive & (Nakashima et al., 2007) \\
\hline NAC & SNAC1 & O. sativa & $\begin{array}{l}\text { RWC, chlorophyll } \\
\text { content }\end{array}$ & $\begin{array}{l}\text { Drought avoidance, signaling } \\
\text { cascade and transcriptional } \\
\text { regulation }\end{array}$ & ABA responsive & (Saad et al., 2013) \\
\hline NAC & TaNAC69 & T. aestivum & Multiple & $\begin{array}{l}\text { Drought avoidance, signaling } \\
\text { cascade and transcriptional } \\
\text { regulation }\end{array}$ & ABA responsive & (Xue et al., 2011) \\
\hline Zinc Finger & DST & & Survivability & $\begin{array}{l}\text { Drought tolerance, signaling } \\
\text { cascade and transcriptional } \\
\text { regulation }\end{array}$ & & (Huang et al., 2009) \\
\hline Zinc Finger & ZFP252 & O. sativa & Survivability & $\begin{array}{l}\text { Drought tolerance, signaling } \\
\text { cascade and transcriptional } \\
\text { regulation }\end{array}$ & & (Xu et al., 2008) \\
\hline Zinc Finger & Zat10 & A. thaliana & Yield, seed setting rate & $\begin{array}{l}\text { Drought tolerance, signaling } \\
\text { cascade and transcriptional } \\
\text { regulation }\end{array}$ & & (Xiao et al., 2009) \\
\hline ZincFinger & OsMYB2 & O. sativa & Survivability & $\begin{array}{l}\text { Drought tolerance, signaling } \\
\text { cascade and transcriptional } \\
\text { regulation }\end{array}$ & & (Yang et al., 2012) \\
\hline
\end{tabular}




\begin{tabular}{|c|c|c|c|c|c|c|}
\hline Functional category & Gene & Species & Parameters evaluated & Mechanisms & Pathways & References \\
\hline Zinc Finger & TaPIMP1 & T. aestivum & $\begin{array}{l}\text { Water loss, proline } \\
\text { content }\end{array}$ & $\begin{array}{l}\text { Drought tolerance, signaling } \\
\text { cascade and transcriptional } \\
\text { regulation }\end{array}$ & & (Zhang et al., 2012) \\
\hline Zinc Finger & StMYB1R-1 & S. tuberosum & Multiple & $\begin{array}{l}\text { Drought tolerance, signaling } \\
\text { cascade and transcriptional } \\
\text { regulation }\end{array}$ & & (Shin et al., 2011) \\
\hline Zinc Finger & OsWRKY11 & O. sativa & Survivability & $\begin{array}{l}\text { Drought tolerance, signaling } \\
\text { cascade and transcriptional } \\
\text { regulation }\end{array}$ & & (Wu et al., 2009) \\
\hline Zinc Finger & OsWRKY30 & O. sativa & Survivability & $\begin{array}{l}\text { Drought tolerance, signaling } \\
\text { cascade and transcriptional } \\
\text { regulation }\end{array}$ & & (Shen et al., 2012) \\
\hline Zinc Finger & $\begin{array}{l}\text { ZPT2-3, } \\
\text { CpMYB10 }\end{array}$ & Petunia & $\begin{array}{l}\text { Better survival rate } \\
\text { during drought stress }\end{array}$ & $\begin{array}{l}\text { Drought tolerance, signaling } \\
\text { cascade and transcriptional } \\
\text { regulation }\end{array}$ & & (Sugano et al., 2003) \\
\hline Osmotic Adjustment & $\begin{array}{l}\text { P5CS } \\
\text { (Pyrroline-5- } \\
\text { carboxylate } \\
\text { synthase) }\end{array}$ & O. sativa & $\begin{array}{l}\text { Increase in biomass } \\
\text { accumulation }\end{array}$ & Drought tolerance & & (Zhu et al., 1998) \\
\hline OsmoticAdjustment & $\mathrm{SacB}$ & Beta vulgaris & $\begin{array}{l}\text { Better dry weight } \\
\text { accumulation }\end{array}$ & Drought tolerance & & (Pilon-Smits et al., 1999) \\
\hline OsmoticAdjustment & $\begin{array}{l}\text { TPS (Trehalose- } \\
\text { 6-phophate } \\
\text { synthetase) }\end{array}$ & N. tabacum & $\begin{array}{l}\text { Delay in withering or } \\
\text { enhanced moisture } \\
\text { retention capacity }\end{array}$ & Drought tolerance & & (Holmström et al., 1996) \\
\hline
\end{tabular}


TABLE 4. Contd.

\begin{tabular}{|c|c|c|c|c|c|c|}
\hline Functional category & Gene & Species & Parameters evaluated & Mechanisms & Pathways & References \\
\hline Osmotic Adjustment & $\begin{array}{l}\text { IMT1 (myo- } \\
\text { Inositol-O-methyl } \\
\text { transferase) }\end{array}$ & Tobacco & $\begin{array}{l}\text { Less inhibition in } \\
\text { photosynthetic rate; } \\
\text { better recovery from } \\
\text { stress }\end{array}$ & Drought tolerance & & (Sheveleva et al., 1997) \\
\hline Osmotic Adjustment & $\begin{array}{l}\text { Trehalose-6- } \\
\text { phophate synthetase }\end{array}$ & Tobacco & $\begin{array}{l}\text { Increased leaf area, } \\
\text { better photosynthetic } \\
\text { activity and better RWC }\end{array}$ & Drought tolerance & & (Pilon-Smits et al., 1999) \\
\hline Osmotic Adjustment & $\begin{array}{l}\text { Trehalose-6- } \\
\text { phophate } \\
\text { synthetase }\end{array}$ & O. sativa & $\begin{array}{l}\text { Better plant growth and } \\
\text { less photooxidative } \\
\text { damage }\end{array}$ & Drought tolerance & & (Garg et al., 2002) \\
\hline Osmotic Adjustment & TPS and TPP & O. sativa & $\begin{array}{l}\text { Better growth } \\
\text { performance and } \\
\text { photosynthetic capacity }\end{array}$ & Drought tolerance & & (Jang et al., 2003) \\
\hline Osmotic Adjustment & AtPLC1 & A. thaliana & & Drought tolerance & & (Hirayama et al., 1995) \\
\hline Osmotic Adjustment & OsTPS1 & O. sativa & Survivability & Drought tolerance & & (Li et al., 2011) \\
\hline Osmotic Adjustment & $m t \mid D$ & E. coli & Multiple & Drought tolerance & & (Abebe et al., 2003) \\
\hline ROS Scavenging & OsSR01c & O. sativa & Mutiple & Drought tolerance & ABA responsive & (You et al., 2012) \\
\hline ROS Scavenging & $\begin{array}{l}\text { MnSOD } \\
\text { (superoxide } \\
\text { dismutase) }\end{array}$ & Alfalfa & $\begin{array}{l}\text { Better photosynthetic } \\
\text { efficiency, yield } \\
\text { and survival rate }\end{array}$ & Drought tolerance & ABA responsive & (McKersie et al., 1996) \\
\hline
\end{tabular}




\begin{tabular}{|c|c|c|c|c|c|c|}
\hline Functional category & Gene & Species & Parameters evaluated & Mechanisms & Pathways & References \\
\hline ROS Scavenging & $\begin{array}{l}\text { MsALR } \\
\text { (Aldose/aldehyde } \\
\text { reductase) }\end{array}$ & Alfalfa & $\begin{array}{l}\text { Decreased lipid } \\
\text { peroxidation and } \\
\text { better photosynthetic } \\
\text { activity }\end{array}$ & Drought tolerance & ABA responsive & (Oberschall et al., 2000) \\
\hline ROS Scavenging & $\begin{array}{l}\text { AtALDH3 } \\
\text { (Aldehyde } \\
\text { dehydrogenase) }\end{array}$ & A. thaliana & $\begin{array}{l}\text { decreased lipid } \\
\text { peroxidation }\end{array}$ & Drought tolerance & ABA responsive & (Sunkar et al., 2003) \\
\hline ROS Scavenging & $\begin{array}{l}\text { Ascorbate } \\
\text { peroxidase }\end{array}$ & N. tabacum & $\begin{array}{l}\text { Better photosynthetic } \\
\text { capacity under water } \\
\text { stress }\end{array}$ & Drought tolerance & ABA responsive & (Hamid Badawi et al., 2004) \\
\hline Protein Kinase & OsCDPK & O. sativa & $\begin{array}{l}\text { Enhanced levels of } \\
\text { stress-responsive } \\
\text { genes, rab16A, SalT, } \\
\text { and wsi18. Stomatal } \\
\text { movement }\end{array}$ & $\begin{array}{l}\text { Signaling cascade and } \\
\text { transcriptional regulation }\end{array}$ & ABA responsive & (Saijo et al., 2000) \\
\hline Protein Kinase & DSM1 & O. sativa & Plant growth. & $\begin{array}{l}\text { Signaling cascade and } \\
\text { transcriptional regulation }\end{array}$ & ABA responsive & (Ning et al., 2010) \\
\hline Protein Kinase & OsSIK1 & O. sativa & Survivability. & $\begin{array}{l}\text { Signaling cascade and } \\
\text { transcriptional regulation }\end{array}$ & ABA responsive & (Ouyang et al., 2010) \\
\hline Protein Degradation & OsDIS1 & O. sativa & Survivability & & & (Ning et al., 2011) \\
\hline Protein Degradation & OsDSG1 & O. sativa & Fresh weight & & & (Park et al., 2010) \\
\hline Protein Degradation & OsSDIR1 & O. sativa & Survivability & & & (Gao et al., 2011) \\
\hline Protein Degradation & OsRDCP1 & O. sativa & Survivability & & & (Bae et al., 2011) \\
\hline
\end{tabular}


TABLE 4. Contd.

\begin{tabular}{|c|c|c|c|c|c|c|}
\hline Functional category & Gene & Species & Parameters evaluated & Mechanisms & Pathways & References \\
\hline Protein Modification & SQS1 & O. sativa & $\begin{array}{l}\text { Survivability, } \\
\text { relative yield }\end{array}$ & & & (Manavalan et al., 2012) \\
\hline Nuclear Proteins & OsSKIPa & O. sativa & Survivability, yield & $\begin{array}{l}\text { Drought tolerance } \\
\text { Transcriptional co-regulator }\end{array}$ & & (Hou et al., 2009) \\
\hline Nuclear Proteins & OsRIP18 & O. sativa & Survivability & $\begin{array}{l}\text { Drought tolerance } \\
\text { Transcriptional co-regulator }\end{array}$ & & (Jiang et al., 2012) \\
\hline Metabolism OfAba & DSM2 & O. sativa & $\begin{array}{l}\text { Survivability, seed } \\
\text { setting rate }\end{array}$ & & & (Du et al., 2010) \\
\hline $\begin{array}{l}\text { Metabolism of Other } \\
\text { Hormones }\end{array}$ & IPT & $\begin{array}{l}\text { A. } \\
\text { tumefaciens }\end{array}$ & Yield, biomass & & & (PELEG et al., 2009) \\
\hline Dehydrin/LEA & OsLEA3-1 & O. sativa & Yield, seed setting rate & Drought tolerance & ABA responsive & (Xiao et al., 2007) \\
\hline Dehydrin/LEA & OsLEA3-2 & O. sativa & $\begin{array}{l}\text { Survivability, grains } \\
\text { per spike }\end{array}$ & Drought tolerance & ABA responsive & (Duan and Cai, 2012) \\
\hline Dehydrin/LEA & HVA1 & H. vulgare & $\begin{array}{l}\text { Plant growth, } \\
\text { survivability, RWC }\end{array}$ & Drought tolerance & ABA responsive & (Babu et al., 2004) \\
\hline Transporter & AtNHX1 & A. thaliana & seed setting rate & Drought tolerance & & (Xiao et al., 2009) \\
\hline Transporter & betA, TsVP & E. coli & Mutiple & Drought tolerance & & (Wei et al., 2011) \\
\hline Amino Acid Metabolism & OsOAT & O. sativa & $\begin{array}{l}\text { Survivability, relative } \\
\text { seed setting rate }\end{array}$ & & & (You et al., 2012) \\
\hline
\end{tabular}


including, the vegetative, reproductive and grain filling stages at varying degrees depending on the species (Blair et al., 2010). In soybean, the loss of seed yield was reported to be maximal when drought appeared during anthesis and the early reproductive stages (Liu et al., 2003; Eslami et al., 2010). As water resources available for agriculture are expected to decrease and becoming unpredictable due to climate change, the need to adopt and enhance drought-resistant in plants is essential to help to produce enough food for the ever increasing world population, and maintain environmental resilience in agriculture. For example, advanced lines BAT477 and SEA5 that are highly drought tolerant have been identified in common bean (Singh et al., 2001; Teran and Singh 2002). Furthermore, Budak et al. (2013) reported the introgression of wild emmer wheat, which is highly drought tolerant, into modern wheat cultivars in order to obtain drought related candidate genes for breeding purpose.

Effect of drought stress on bambara groundnut. For bambara groundnut, several studies have been carried out to investigate the response to drought stress. Under drought stress, bambara groundnut landrace AS-17 showed paraheliotropic properties, in which the stressed plants had leaflet angles parallel to the incident radiation, leading to less transpiratory water loss due to the lower leaf temperature that resulted from decreased light interception (Stadler, 2009). From the results of Mabhaudhi et al., (2013), bambara groundnut was observed to have drought escape mechanisms where, under drought stress, it had a shortened vegetative growth period, early flowering, reduced reproductive stage and early maturity in order to minimise the adverse effect of drought on plant development. Higher root dry weight was reported when bambara groundnut landrace, Burkina (originally from Burkina Faso), was subjected to drought (Berchie, 2012). Denser and deeper root growth will allow the plant to utilise more soil moisture under drought stress. Stomatal closure plays an important role in regulating transpiration and improve plant water status over the drought stress period. Stomatal closure has been recognised as a universal response to drought stress in many species, such as rice (oryza sativa) (Huang et al., 2009), maize (Zea mays) (Benešová et al., 2012) and has been reported for bambara groundnut (Collinson et al., 1997; Vurayai et al., 2011). Accumulation of proline was observed in bambara groundnut under drought stress which plays a vital role in osmotic adjustment (Collinson et al., 1997). Furthermore, (Vurayai et al., 2011) stated that reduced leaf area in drought-stressed bambara groundnut plants due to turgor reduction within expanding cells is common and is one of the earliest physiological responses to water stress. Bambara groundnut is more vulnerable to drought during the pod filling stage, followed by the flowering stage and then the vegetative stage, as plants stressed at the pod filling stage failed to fully recover their relative water content and chlorophyll fluorescence after irrigation was resumed (Vurayai et al., 2011).

Understanding and optimising the responses of bambara groundnut under drought is of central importance in order to identify the key features of the crop which need breeding attention. Drought experiments in bambara groundnut will help to identify novel drought-related genes which could be of great importance to understand biochemical and physiological behaviour of this plant during drought stress.

In an effort to generate drought transcriptomic data for this crop at relatively low cost, NGS technology can be used directly to develop molecular markers by generating transcriptomes (ESTs) which will then be used to identify candidate genes responsible for the crop's response to drought stress. Additional molecular markers can be discovered from translational genomics-based approaches including investigating known gene regulatory networks involved in drought stress response and tolerance in other species. For example, with the help of genomics, transcriptional regulatory networks of drought stress signals were identified in range of species (Shinozaki and YamaguchiShinozaki, 2006), which will help in genomic study of less studied crops, such as bambara groundnut. Use of molecular markers for an agronomically important trait such as drought in underutilised crops, in this example bambara groundnut, will assist the integration of desirable alleles into specific genotypes that will contribute 
to improvement of breeding lines and the development of drought tolerant cultivars.

Use of advanced genomics and transcriptomics for research and development in bambara groundnut

Advancement in crop genome sequencing and analysis. Significant progress in sequencing technologies have speeded up the time and lowered the cost per base pair, allowing a step change in access to crop genomes compared to the previous era of Sanger-based sequencing. Before the invention of next generation sequencing technologies, Sanger sequencing of bacterial artificial chromosome (BAC)-based physical maps was the main approach for genome sequencing of species, such as rice, maize and poplar (Populus tremula) (Schnable et al., 2009). Though physical maps of BACs provided a good template for completing gaps and correcting sequencing errors, the genome coverage of physical maps was non-representative due to cloning bias and was relatively labour intensive. With the availability and advancement of next generation sequencing, it is possible to sequence large volumes of DNA faster, and with better genome coverage (Metzker, 2010). In 2010, the African Orphan Crop Consortium (AOCC) was launched with the aim to sequence 101 indigenous African crops. Bambara groundnut is one of the target species for sequencing, with the genome sequence generated from a variety from Zimbabwe (Mana), and resequencing will be performed on 100 genotypes developed over the years by multiple research organisations. The draft genome of bambara groundnut is expected to be published in the third quarter of 2016.

\section{Molecular marker systems and breeding for} drought resistance using omic technologies

Marker-assisted selection from major species to bambara groundnut. With the help of advanced genomic and transcriptomic data, breeders can have access to putative gene function, gene content, copy number variation between varieties, precise genomic positions and identification of both natural and induced variation in germplasm collections. In addition, promoter sequences allows epigenetic analysis and expression levels to be monitored in different tissues or environments and in specific genetic backgrounds using NGS and microarray technologies (Bevan and Uauy, 2013).The significant reduction in cost and increased accessibility of omic technologies (Shendure and Lieberman Aiden, 2012) has made genome-wide analysis of less studied crops possible. The availability of molecular markers and genetic linkage maps in many plant species, such as Medicago truncatula (Thoquet et al., 2002), common bean (Freyre et al., 1998), soybean (Song et al., 2004) and cowpea (Menendez et al., 1997) have made it possible to dissect complex traits into individual quantitative trait loci (QTL), with sequencing and annotation of large genomics DNA fragments. Marker-assisted breeding approaches will help in identifying important agronomic traits corresponding to various biotic and abiotic stresses (McCouch et al., 2002). Sequence data derived from medicago truncatula, soybean, cowpea and common bean can be used to develop cross-species simple sequence repeat (SSR) markers. For example, Medicago truncatula based SSRs provided genetic markers for linkage mapping in alfalfa (Medicago sativa) (Sledge et al., 2005) and more distantly related crop legumes (Gutierrez et al., 2005; Zhang et al., 2007). This approach can be applied in bambara groundnut, where a closely related legume crop sequence data, such as common bean, mung bean or soybean can help in identifying molecular markers for the traits of interest. Furthermore, with the help of genome sequencing of major legume crops targeting genes for the specific traits of interest in crop relatives, such as drought resistance, is possible. In this approach, phenotypes of interest in crop relatives are mapped and characterised against major crops using the available genomic resources (Fig. 1) (Young and Udvardi, 2009), This strategy should be applicable to most closely related legume crops and can be applied in bambara groundnut. It was successful in Medicago truncatula, where phenotypic mapping was performed in Medicago truncatula ranging from disease resistance genes to QTL for morphology. Resistance against Colletotrichum trifolii (anthracnose) (Ameline- 
Torregrosa et al., 2007; Yang et al., 2008), Phoma medicagnis (black steam and leaf spot) (Kamphuis et al., 2008), and Erysiphe pisi (powdery mildew) (Ameline-Torregrosa et al., 2007) have all been mapped in Medicago truncatula. The cloned RCT1 gene found in Medicago trunculata for resistance to anthracnose has been shown to function in alfalfa (Yang et al., 2008)

With the help of genomic and transcriptomic analysis, sequence data derived from major species will help in the development of new molecular markers for drought resistance and gene discovery in underutilised crops, leading to crop improvement. Though MAS has been implemented in many crop breeding programmes, it still at a primitive stage for many minor and underutilised crops. Perhaps one of the biggest challenges many underutilised crops face is the absence of structured genetic resources that allow a powerful dissection of the genetic control of complex traits. Many traits are governed by multiple genes and it is more difficult to understand the underlying genetic control of these quantitative traits, without structured (and preferably immortal) populations and genetic stocks. Additionally, imprecise localisation of the QTLs and instability of QTL between experiments and environments adds to the complexity of this approach for underutilised species (Nelson et al., 2004).

Genomic-assisted breeding for drought resistance. The availability of advanced expression analysis techniques such as NGS, microarrays, real-time PCR, transcriptomics, proteomics and metabolomics platforms have made it possible to carry out extensive gene expression analysis to identify and characterise candidate genes for drought tolerance (Swamy and Kumar 2013) (Table 4). Breeding for drought resistance is challenging as it is a complex trait controlled by many genes, there is limited knowledge of the inheritance mechanisms and the effect of drought is different for every genotype (Shashidhar et al., 2013). Knowledge of the relative values of the alternative alleles at all loci segregating in a population could allow breeders to design a genotype in silico (Varshney et al., 2005). Marker-assisted backcrossing approaches and marker-assisted

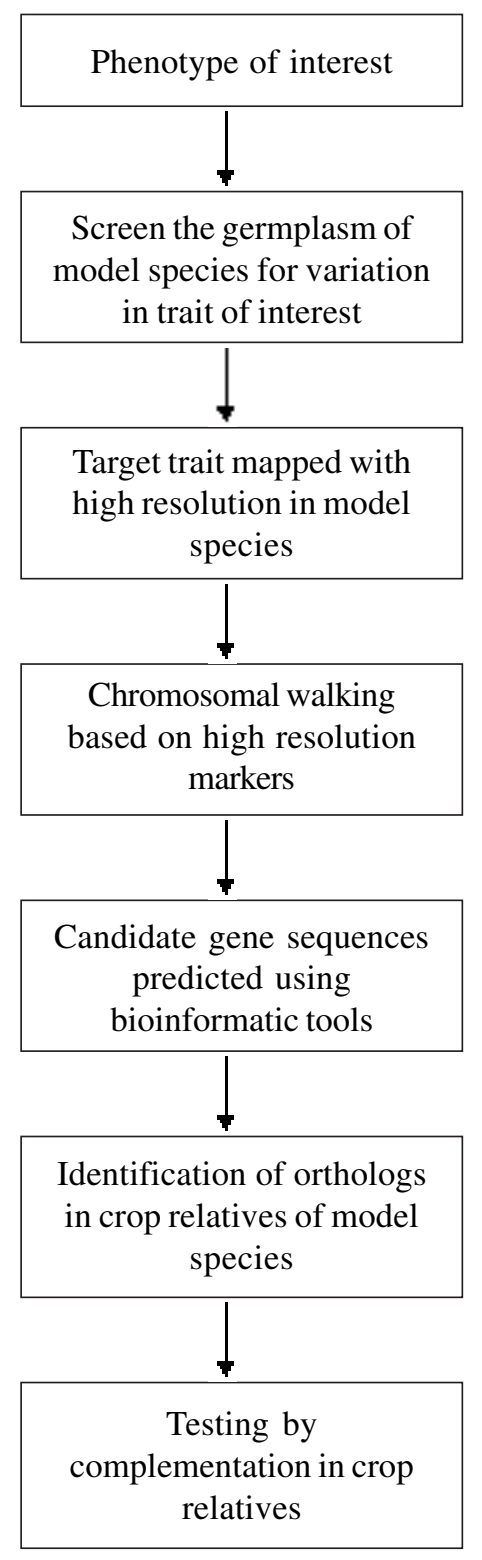

Figure 1. Gene discovery in underutilised species from model species. Key steps listed, where a model species was used to find gene of interest based on genome location (Young and Udvardi, 2009)

recurrent selection have been implemented in legume crops such as chickpea to improve the crop's drought resistance (Thudi et al., 2014). With the recent advances in genomic technologies and the availability of genomic platforms, the cost of genotyping has become much cheaper than phenotyping. Breeding 
approaches, such as marker-assisted backcrossing approaches and marker-assisted recurrent selection have recently been complemented by a new approach called genomic selection (GS), which predicts the breeding values (i.e genomics assisted breeding values; GEBVs) of lines in the next generation based on historical genotyping and phenotyping data (Meuwissen et al., 2001; Morrell et al., 2011). GS has begun to be incorporated into breeding programs for crops, although many questions remain in terms of which crops are most suited and what some of the key parameters for successful deployment are (Eathington et al., 2007). With genome coverage provided by GS, NGS will help in providing estimates of gene expression levels and determination of epigenetic states of genes (Bevan and Uauy, 2013).

To date, there has been no broad screening of the bambara groundnut germplasm under drought stress. Though the crop is known to be drought-tolerant from the physiology point of view, drought tolerance should be linked to comparatively higher growth rates and productivity under water stress conditions. In bambara groundnut, populations were analysed for specific genetic traits of interest which includes genetic mapping of photoperiod response in bi-parental populations after development of single genotype parental lines (Kendabie et al., 2013) and mapping of phenotypic traits associated with domestication syndrome in bambara groundnut and plant morphology (Ahmad et al., 2013; Basu et al., 2007; Chai et al., 2013). The genotypes obtained from crosses in bambara groundnut are important resources to study and optimise for specific traits throughbreeding programmes (Aliyu et al., 2015). Genomic resources including SSR markers in bambara groundnut were developed and will be employed in identification of QTLs for specific physiological traits relevant for drought tolerance (Beena et al., 2012). Results from Beena et al. (2012) showed that there was a significant reduction in the physiological (transpiration, photosynthesis and chlorophyll content) and morphological (leaf area, total biomass) traits under water limiting conditions. The availability of SSR (Beena et al., 2012; Molosiwa et al., 2015) and DArT (Olukolu et al., 2012) markers of bambara groundnut have made it possible to carry out diversity analysis, mapping of QTLs for various agronomics traits under drought and their use in marker-assisted breeding. Random amplified polymorphic DNA (RAPD) and fluorescence based amplified fragment length polymorphism (AFLP) have been developed for several landraces of bambara groundnut and the study revealed high levels of polymorphism among landraces (Massawe et al., 2002). Genetic linkage maps of bambara groundnut were constructed by combining microsatellite and DArT markers from a 'narrow' and 'wide' cross between bambara groundnut landraces Tiga Necaru x DipC and DipC x VSSP11 to identify marker-trait linkages and to develop the crop through marker-assisted selection by selecting marker allele that is linked to a trait of interest (Basu et al.,2003; Ahmad, 2016). The genetic map created from the Tiga Necaru x DipC cross was based on an intra-sub-specific cross exploits variation within the domesticated landraces gene pool, using an $\mathrm{F}_{3}$ population of the cross between DipC and Tiga Necaru (Ahmad et al., 2016, 2013; Chai, 2014; Chai et al., 2015). This cross showed variation for agronomic traits of breeding interest. This map will be useful for comparative genomic analysis between the mapping populations in this crop and also between bambara groundnut and other related legume crops (Ahmad et al., 2013). Based on the results from the 'narrow' genetic cross $\left(\mathrm{F}_{3}\right.$ generation) and 'wide' genetic cross ( $\mathrm{F}_{2}$ generation) for Tiga Necaru $\mathrm{x}$ DipC and DipC $\mathrm{x}$ VSSP11, respectively, a candidate marker bgPabg-596774 was identified for the following traits; pod number, node number, pod weight, seed number, seed weight and biomass dry weight which could be used for MAS (Ahmad et al., 2013). Development of the population (Tiga Necaru x DipC and DipC x VSSP11) into full Recombinant Inbred Lines (RILs) (at $\mathrm{F}_{6}$ generation currently) or the development of Near Isogenic Lines (NILs) could allow the evaluation of the effects of these QTL alone and also the development of heterozygous plants for the QTL region, allowing_large-scale fine mapping programme (Ahmad et al., 2013).

Due to the limited understanding of the drought response mechanisms that are active in different germplasm within bambara groundnut, 
implementing molecular breeding for drought resistance or selection of candidate genes for gene editing is challenging. Furthermore, high temperature is usually co-incidental with drought stress. Therefore, a single gene effect to increase drought resistance is possible, but the combined stress may require a multi-gene transformation strategy that combines several major functional or regulatory genes or a series of genes in a signalling cascade contributing to drought resistance seems promising for improving long term drought resistance in plants (Hu and Xiong, 2014). In addition, combining traditional breeding (such as cross and/or recurrent backcrossing of wild relatives and elite cultivars) will help in building the desired traits for abiotic resistance (Hu and Xiong, 2014) in bambara groundnut.

Comparative genomics and transcriptomics from major species to bambara groundnut. Advances in crop genomics, transcriptomics, molecular and bioinformatic tools have given us an opportunity to understand plant biology in a more unified way and also help transfer information from a major species to minor species (Akpinar et al., 2013). Strong conventional breeding practice is required for successful genomic investment on underutilised crops (Nelson et al., 2004). Exploiting biotechnological tools and translation research from major species to underutilised crops will lead to better results in breeding processes using two main methods (1) translation of technologies, such as marker system approaches based on next generation sequencing (2) translation of actual genetic-trait information from related species based on locational or network analysis (Aliyu et al., 2015).

Comparative genomics. Comparative genomics has been widely used in modern day research as it can provide important information about species whose genomes have not been sequenced by comparing with a known species (Dhanapal, 2012). Rapid advancement in crop genomics has provided a chance to conduct detailed functional and structural comparisons of genes involved in various biological processes among major crops and other plant species. Therefore, comparative genomics using bioinformatic tools can provide an opportunity for transferring important information from major species to bambara groundnut. Some examples that illustrate comparative genomics in legumes are; (1) Use of barrel medic to map-based clone the RCT gene that confers resistance to multiple races of anthracnose (Colletotrichum trifolii) in alfalfa (Yang et al., 2008), (2) Floral regulatory genes identified in Arabidopsis (Arabidopsis thaliana) were used to find genes in common bean effecting determinacy (Cannon et al., 2009) and (3) Identification of the gene underlying Mendel's I locus, responsible for the trait corresponding to yellow or green colour of seed in grass meadow fescue (Armstead et al., 2007). A candidate gene that plays a critical role in cholorophyll catabolism during plant senescence was found in rice and later its orthologous gene was fine mapped in pea (Pisum sativum). Thus traits, genes, tools and species were combined to link this trait and the underlying gene in several models and crops (Armstead et al., 2007). In addition, minor crops can provide good models for a trait and trait analysis absent in major crops (Nelson et al., 2004). For example, if alleles contributing drought tolerance can be found in bambara groundnut, the underlying physiological mechanism and the genes responsible could be useful and can be utilised by MAS to search for alleles within the species of interest or the trait might be transferred through direct gene transfer into major crops

Comparative transcriptomics. Comparative transcriptomics has been tested in bambara groundnut. Comparisons between the bambara groundnut leaf transcriptome and other species has been carried out to identify appropriate crossspecies orthologues and gene models for the crop (Mayes et al., 2013). The results showed that soybean had the highest transcript sequence similarity to bambara groundnut than any other species used in the analysis (other species were Medicago truncatula, Vitis vinifera, Populas trichocarpa, Ricinis communis, Arabidopsis lyrata, Vigna radiata) and could potentially be used as a gene model for gene expression profiling in bambara groundnut (Mayes et al., 2013), although the tetraploid nature of soybean adds complications. 
Bambara groundnut DNA was hybridised to Arabidopsis ATH1 and Medicago truncatula Affymetrix GeneChips for high and low stem number respectively as there is no Affymetrix GeneChip available for bambara groundnut (Chai et al., 2013; Chai et al., 2015). The cross species microarray approach coupled with genetical genomics has been applied on bambara groundnut using the soybean Gene Chip array. The drought experiment conducted by (Chai, 2014) used leaf RNA from an $F_{5}$ segregating population derived from a controlled cross of between DipC and Tiga Necaru cross-hybridised to the soybean GeneChip ${ }^{\mathrm{TM}}$ from Affymetrix. The results identified 1531 good quality gene expression markers (GEMs) on the basis of differences in the hybridisation signal strength. An expression based genetic map was constructed using 165 GEMs. Significant QTLs were detected using the GEM map for various morphological traits (including internode length, peduncle length, pod number per plant, pod weight per plant, seed number per plant, seed weight per plant, 100-seed weight, shoot dry weight). An XSpecies microarray experiment was conducted in order to identify and detect genes and gene modules associated with low temperature stress responses in bambara groundnut. This found 375 and 659 differentially expressed genes $(\mathrm{p}<0.01)$ under the sub-optimal $\left(23^{\circ} \mathrm{C}\right)$ and very sub-optimal $\left(18^{\circ} \mathrm{C}\right)$ temperatures, respectively. Further, 52 out of top 100 differentially expressed genes were validated using NGS technology generated from the same samples used to generate cross-species microarray data. The results showed $>50 \%$ similarity between the XSpecies Microarray approach and NGS technology. The identified gene modules could be useful in breeding for low-temperature stress tolerant bambara groundnut varieties (Bonthala et al., 2015). These approaches have the potential to identify polymorphisms between individuals for gene expression analysis and mutation discovery (Mardis, 2008), which will accelerate the generation of markers for specific traits in minor crop species (Chai et al., 2013).

\section{CONCLUSION}

Recent developments in genomics and transcriptomics have opened up opportunities to develop data sets for several underutilised species which could facilitate crop improvement. Genomics has led us to gather a wealth of information from the identification of genetic variation, epigenetic states of genes and the potential to measure gene expression with high precision and accuracy. This will not only benefit breeding but also facilitates systematic comparison of gene functions across sequenced genomes which will directly benefit crop improvement. Projects, such as Encyclopedia of DNA elements (ENCODE) (although yet to be implemented in plants) will build a foundation for extracting knowledge of gene function and variation, thus generating new data for the prediction of phenotype from genotype (Bevan and Uauy, 2013). Knowledge gained from integration of gene function into networks, such as controlling flowering time in response to day length and over-wintering will pave the way for crop improvement. These networks have been identified in Arabidopsis and Rice, with allelic variation strongly influencing networks outputs. Processes, such as gene duplication and footprints of domestication can be mapped to networks such as flowering time (Yan et al., 2006; Higgins et al., 2010). Improved precision of predicting the phenotype from genotype is possible with the use of 'systems breeding' approaches which use diverse genomic information leading to food security and crop improvement (Bevan and Uauy, 2013).

The improvement in genomics and transcriptomics will help in identifying target genes that underlie key agronomic traits related to drought. Molecular markers will be developed using the information gained from the trait of interest which will be later on used for breeding applications. Finding gene targets that are related to various biotic and abiotic stresses will be productive towards the aim of crop improvement, as plant growth is severely effected by stresses, such as drought, cold and salt especially in 
marginal physical and economic environments. Molecular analysis of bambara groundnut germplasm using advanced genomic tools will help in the discovery of genes for key agronomic traits. Functional genomic tools, physical maps and the availability of high-throughput and costeffective genotyping platforms will all contribute towards crop improvement. There are various challenges that have to be looked upon before applying genomics to underutilised crops. Most of the underutilised crops lack large-scale collections of germplasm, although local communities and small-scale farmers do have extensive knowledge that help in the search for genes that are vital for crop improvement. Restriction on flow of germplasm due to intellectual property rights is also one of the major challenges (Bhattacharjee, 2009).

The potential value of underutilised crops (and bambara groundnut) is the part they can play in minimising Africa's challenges of rural development, hunger, malnutrition and gender inequality. Bambara groundnut is resilient and reliable crop that thrives in unsuitable areas which could potentially be unsuitable for peanut, maize, or even sorghum (Sorghum bicolor) (Murevanhema and Jideani, 2013). It is mainly reported to be grown by women, therefore, offers a reliable way of empowering women financially, hence improving the lives of their families (National Research Council, 1996). As a legume, it has the ability to fix atmospheric nitrogen either as an intercrop or rotational crop, thus minimising the use of chemical fertilisers. Being a cheap source of soil nitrogen, it can help resource-poor farmers to achieve some added nitrogen for the growth of the main crop.

The Green Revolution only ever partially succeeded in Africa, but has led to a focus on major crops which, in some cases, are been grown in the wrong places and under the wrong agricultural systems for them to ever be truly productive. Investigating the many underutilised crops which exist as a component of climate resilient, low input, agriculture is one way to mitigate the risk of total crop failure. The advent of next generation sequencing has opened up the possibilities for minor crops, allowing both within species analysis and comparative analysis to related species. Access to germplasm is still a significant issue, but the tools to begin a more context and nutritionally focused agricultural revolution are coming into place.

\section{ACKNOWLDEGMENT}

I thank Aryo Feldman for his helpful comments on the manuscript.

\section{REFERENCES}

Abdualrahman, M.A.Y., Ali, A.O., Elkhalifa, E.A. and Sulieman, A.E. 2012. Effect of bambara groundnut flour (Vigna subterranea (L.) Verdc.) supplementation on chemical, physical, nutritional and sensory evaluation of wheat bread. Pakistan Journal of Biological Sciences 15:845-9.

Abebe, T., Guenzi, A.C., Martin, B. and Cushman, J.C. 2003. Tolerance of mannitol-accumulating transgenic wheat to water stress and salinity. Plant Physiology 131:1748-55. doi:10.1104/ pp.102.003616

Ahmad, N., Redjeki, E., Kuan, W., Aliyu, S., Mayes, K., Massawe, F., Kilian, A. and Mayes, S. 2016. Construction of a genetic linkage map and QTL analysis in bambara groundnut. Genome 59.

Ahmad, N.S., Basu, S.M., Redjeki, E.S., Murchie, E., Massawe, F., Azam-Ali, S., Kilian, A. and Mayes, S. 2013. Developing genetic mapping and marker-assisted breeding techniques in Bambara groundnut (Vigna subterranea $\mathrm{L}$.). Acta Horticulturae 979:437-450.

Akpinar, B.A., Lucas, S.J., Budak, H. and Akpýnar, B.A. 2013. Genomics approaches for crop improvement against abiotic stress. The Scientific World Journal 361921. doi:10.1155/ 2013/361921

Aliyu, S., Massawe, F. and Mayes, S. 2016. Genetic diversity and population structure of Bambara groundnut (Vigna subterranea (L.) Verdc.): Synopsis of the past two decades of analysis and implications for crop improvement programmes. Genetic Resources and Crop Evolution 63: 925-943. doi:10.1007/ s10722-016-0406-Z

Aliyu, S., Massawe, F. and Mayes, S. 2015. Beyond landraces/ : developing improved germplasm resources for underutilized 
species - a case for Bambara groundnut. Biotechnology and Genetic Engineering Reviews 37-41. doi:10.1080/02648725.2014. 992625

Ameline-Torregrosa, C., Cazaux, M., Danesh, D., Chardon, F., Cannon, S.B., Esquerre-Tugaye, M.T., Dumas, B., Young, N.D., Samac, D.A., Huguet, T., Jacquet, C., Esquerré-Tugayé, M.T., Dumas, B., Young, N.D., Samac, D.A., Huguet, T. and Jacquet, C. 2007. Genetic Dissection of resistance to anthracnose and powdery mildew in Medicago truncatula. Molecular Plant-Microbe Interactions 21:61-69. doi:10.1094/MPMI-21-1-0061

Anyia, A. and Herzog, 2004. Water-use efficiency, leaf area and leaf gas exchange of cowpeas under mid-season drought. European Journal of Agronomy 20: 327-339.

Armstead, I., Donnison, I., Aubry, S., Harper, J., Hörtensteiner, S., James, C., Mani, J., Moffet, M., Ougham, H., Roberts, L., Thomas, A., Weeden, N., Thomas, H. and King, I. 2007. Cross-species identification of Mendel's I locus. Science 315:73. doi:10.1126/ science. 1132912

Azam-Ali, S.N., Sesay, A., Karikari, S., Massawe, F.J., Aguilar-Manjarrez, J., Bannayan, M. and Hampson, K. 2001. Assessing the potential of an underutilized crop: A case study using Bambara groundnut. Experimental Agriculture 37.

Babu, R.C., Zhang, J., Blum, A., Ho, T.H.D., Wu, R. and Nguyen, H.T. 2004. HVA1, a LEA gene from barley confers dehydration tolerance in transgenic rice (Oryza sativa L.) via cell membrane protection. Plant Science 166:855862. doi:10.1016/j.plantsci.2003.11.023

Bae, H., Kim, S.K., Cho, S.K., Kang, B.G. and Kim, W.T. 2011. Overexpression of OsRDCP1, a rice RING domain-containing E3 ubiquitin ligase, increased tolerance to drought stress in rice (Oryza sativa L.). Plant Science 180:775-782. doi:10.1016/j.plantsci.2011.02.008

Bamshaiye, O.M., Adegbola, J.A. and Bamishaiye, E.I. 2011. Bambara groundnut/ : an Under-Utilized Nut in Africa. Advances in Agricultural Biotechnology 1: 60-72.

Barimalaa, I. and Anoghalu, S. 1997. Effect of Processing on Certain Antinutrients in Bambara Groundnut (Vigna subterranea)
Cotyledons. Journal of the Science of Food and Agriculture 73:186-188.

Basu, S., Mayes, S., Davey, M., Roberts, J.A., Azam-Ali, S.N., Mithen, R. and Pasquet, R.S. 2007. Inheritance of "domestication" traits in bambara groundnut (Vigna subterranea (L.) Verdc.). Euphytica 157:59-68. doi:10.1007/ s10681-007-9396-4

Basu, S., Roberts, J., Davey, M., Azam-Ali, S. and Mithen, R. 2003. Towards genetic linkage mapping in Bambara groundnut. In: Proceedings of the International Bambara Groundnut Symposium in Gaborone, Botswana. pp. 211-222.

Beena, R., Sheshshayee, M., Madhura, J., Prasad, T. and Udayakumar, M. 2012. Development of SSR markers and genetic variability in physiological traits in Bambara groundnut (Vigna subterranea L. Verdc). In: Prospects in Bioscience: Addressing the Issues. pp. 229242.

Benešová, M., Holá, D., Fischer, L., Jedelský, P., Hnilièka, F. and Wilhelmová, N. 2012. The physiology and proteomics of drought tolerance in maize: Early stomatal closure as a cause of lower tolerance to short-term dehydration? PLoS One 7.

Berchie, J.N. 2012. Evaluation of five bambara groundnut (Vigna subterranea (L.) Verdc.) landraces to heat and drought stress at TonoNavrongo, Upper East Region of Ghana. African Journal of Agricultural Research 7:250-256. doi:10.5897/AJAR11.817

Bevan, M.W. and Uauy, C. 2013. Genomics reveals new landscapes for crop improvement. pp. 4-6. doi:10.1186/gb-2013-14-6-206

Bhattacharjee, R. 2009. Harnessing biotechnology for conservation and utilization of genetic diversity in orphan crops. Atdf Journal 6: 24-31.

Blair, M., Galeano, C., Tovar, E., Muñoz Torres, M., Castrillón, A., Beebe, S. and Rao, I. 2010. Development of a Mesoamerican intragenepool genetic map for quantitative trait loci detection in a drought tolerant $x$ susceptible common bean (Phaseolus vulgaris L.) cross. Molecular Breeding 29:7188.

Bonthala, V.S., Mayes, K., Moreton, J., Blythe, M., Wright, V., May, S., Massawe, F., Mayes, 
S. and Twycross, J. 2015. Identification of gene modules associated with low temperatures response in Bambara groundnut by Network-based Analysis. PLoS One.

Budak, H., Kantar, M., Yucebilgili Kurtoglu, K., 2013. Drought tolerance in modern and wild wheat. The Scientific World Journal. pp. 116.

Cannon, S.B., May, G.D. and Jackson, S.A. 2009. Three sequenced legume genomes and many crop species: Rich opportunities for translational genomics. 151:970-977. doi:10.1104/pp.109.144659

Chai, H., H, L., H, G., S, B., Massawe, F., Graham, S. and Mayes, S., 2013. Developing X Species approaches for genomics and transcriptomics - Using resources developed in major species for research in Bambara. In: 2nd International Symposium on Underutilized Species: Crops for the Future - Beyond Food Security. Acta Horticulture, Kuala Lumpur. pp. 773-778.

Chai, H.H. 2014. Developing new approaches for transcriptomics and genomics - Using major resources developed in model species for research in crop species. M.Sc. Thesis. University of Nottingham, Nottingham.

Chai, H.H., Massawe, F. and Mayes, S. 2015. Effects of mild drought stress on the morphophysiological characteristics of a bambara groundnut segregating population. Euphytica. doi:10.1007/s10681-015-1581-2

Chen, J., Meng, X., Zhang, Y., Xia, M. and Wang, X. 2008. Over-expression of OsDREB genes lead to enhanced drought tolerance in rice. Biotechnology Letters 2191-2198.

Collino, D., Dardanelli, J., Sereno, R. and Racca, R. 2001. Physiological responses of argentine peanut varieties to water stress. Light interception, radiation use efficiency and partitioning of assimilates. Field Crops Research 70: 177-184.

Collinson, S., Clawson, E., Azam-Ali, S.N. and Black, C. 1997. Effects of soil moisture defecits on the water relation of bambara groundnut (Vigna subtarranea L. Verdc). Journal of Experimental Botany 48:877-884.

Coudert, M. 1984. Market openings in West Africa for cowpea and bambara groundnut. In: International Trade Forum 20: 14-29.
Crop Trust - Securing our food, forever. https:// www.croptrust.org/ [Accessed November 20, 2015].

Cui, M., Zhang, W., Zhang, Q., Xu, Z., Zhu, Z., Duan, F. and $\mathrm{Wu}, \mathrm{R}$. 2011. Induced overexpression of the transcription factor OsDREB2A improves drought tolerance in rice. Plant Physiology and Biochemistry 49:1384-1391. doi:10.1016/j.plaphy.2011. 09.012

Dhanapal, A.P. 2012. Genomics of crop plant genetic resources. Advances in Bioscience and Biotechnology 3:378-385. doi:10.4236/ abb.2012.34054

Du, H., Wang, N., Cui, F., Li, X., Xiao, J. and Xiong, L. 2010. Characterization of the beta-carotene hydroxylase gene DSM2 conferring drought and oxidative stress resistance by increasing xanthophylls and abscisic acid synthesis in rice. Plant Physiology 154:1304-18. doi:10.1104/pp.110.163741.

Duan, J. and Cai, W. 2012. OsLEA3-2, an abiotic stress induced gene of rice plays a key role in salt and drought tolerance. PLoS One 7, e45117. doi:10.1371/journal.pone.0045117

Dubouzet, J.G., Sakuma, Y., Ito, Y., Kasuga, M., Dubouzet, E.G., Miura, S., Seki, M., Shinozaki, K. and Yamaguchi-Shinozaki, K. 2003. OsDREB genes in rice, Oryza sativa L. encode transcription activators that function in drought-, high-salt- and cold-responsive gene expression. Plant Journal 33:751-763. doi:10.1046/j.1365-313X.2003.01661.x

Eathington, S.R., Crosbie, T.M., Edwards, M.D., Reiter, R.S. and Bull, J.K. 2007. Molecular markers in a commercial breeding program. Crop Science 47:S-154. doi:10.2135/ cropsci2007.04.0015IPBS

Eslami, S., Gill, G. and McDonald, G. 2010. Effect of water stress during seed development on morphometric characteristics and dormancy of wild radish (Raphanus raphanistrum L.) seeds. International Journal of Plant Production.

Freyre, R., Skroch, P.W., Geffroy, V., AdamBlondon, A.F., Shirmohamadali, A., Johnson, W.C., Llaca, V., Nodari, R.O., Pereira, P.A., Tsai, S.M., Tohme, J., Dron, M., Nienhuis, J., Vallejos, C.E. and Gepts, P. 1998. Towards an integrated linkage map of common bean. 4 . 
Development of a core linkage map and alignment of RFLP maps. Theoretical and Applied Genetics 97:847-856. doi:10.1007/ s001220050964

Gao, T., Wu, Y., Zhang, Y., Liu, L., Ning, Y., Wang, D., Tong, H., Chen, S., Chu, C. and Xie, Q. 2011. OsSDIR1 overexpression greatly improves drought tolerance in transgenic rice. Plant Molecular Biology 76:145-156. doi:10.1007/s11103-011-9775-Z

Garg, A.K., Kim, J.-K., Owens, T.G., Ranwala, A.P., Choi, Y. Do, Kochian, L. V. and Wu, R.J. 2002. Trehalose accumulation in rice plants confers high tolerance levels to different abiotic stresses. Proceedings of the National Academy of Sciences of the United States of America 99:15898-903. doi:10.1073/ pnas.252637799

Gaur, P., Krishnamurthy, L. and Kashiwagi, J. 2008. No Improving drought avoidance root traits in Chickpea (Cicer arietinum L.) - Current status of research at ICRISAT. Plant Production Science 11:3-11.

Godfray, H.C.J., Beddington, J.R., Crute, I.R., Haddad, L., Lawrence, D., Muir, J.F., Pretty, J., Robinson, S., Thomas, S.M. and Toulmin, C., 2010. Food security: The challenge of feeding 9 billion people. Science 327:812-818. doi:10.1126/science. 1185383

Goli, A. 1995. Bambara groundnut: Bibliographical review. In: Bambara groundnut (Vignia Subterranean). Proceedings of the Workshop on Conservation and Improvement of Bambara groundnut (Vignia Subterranean (L.) Verdc.). Harare, Zimbabwe. pp. 4-10.

Gupta, N., Gupta, S. and Kumar, A. 2001. Effect of water stress on physiological attributes and their relationship with growth and yield of wheat cultivars at different stages. Journal of Agronomy and Crop Science 186:55-62.

Gutierrez, M., Vaz Patto, M., Huguet, T., Cubero, J., Moreno, M. and Torres, A. 2005. Crossspecies amplification of Medicago truncatula microsatellites across three major pulse crops. Theor Appl Genet 110:1210-1217.

Haake, V., Cook, D., Riechmann, J.L., Pineda, O., Thomashow, M.F. and Zhang, J.Z. 2002. Transcription factor CBF4 is a regulator of drought adaptation in Arabidopsis. Plant
Physiology 130:639-648. doi:10.1104/ pp.006478

Hamid Badawi, G., Yamauchi, Y., Shimada, E., Sasaki, R., Kawano, N., Tanaka, K. and Tanaka, K. 2004. Enhanced tolerance to salt stress and water deficit by overexpressing superoxide dismutase in tobacco (Nicotiana tabacum) chloroplasts. Plant Science 166:919-928. doi:10.1016/j.plantsci.2003.12.007

Harb, A., Krishnan, A., Ambavaram, M. and Pereira, A. 2010. Molecular and physiological analysis of drought stress in Arabidopsis reveals early responses leading to acclimation in plant growth. Plant Physiology 154:12541271.

Heller, J. 1997. Bambara groundnut: Vigna subterranea (L.) Verdc. promoting the conservation and use of under-utilized and neglected crops. IPGRI, Harare, Zimbabwe.

Higgins, J.A., Bailey, P.C. and Laurie, D.A. 2010. Comparative genomics of flowering time pathways using Brachypodium distachyon as a model for the temperate grasses. PLoS One 5, e10065. doi:10.1371/journal.pone. 0010065

Hillocks, R.J., Bennett, C. and Mponda, O.M. 2012. Bambara Nut: A review of utilisation, market potential and crop improvement. African Crop Science Journal 20:1-16.

Hirayama, T., Ohto, C., Mizoguchi, T. and Shinozaki, K. 1995. A gene encoding a phosphatidylinositol-specific phospholipase $\mathrm{C}$ is induced by dehydration and salt stress in Arabidopsis thaliana. Proceedings of the National Academy of Sciences 92:3903-3907. doi:10.1073/pnas.92.9.3903

Holmström, K., Mäntylä, E., Welin, B. and Mandal, A. 1996. Drought tolerance in tobacco. Nature. doi:10.1038/379683a0

Hou, X., Xie, K., Yao, J., Qi, Z. and Xiong, L. 2009. A homolog of human ski-interacting protein in rice positively regulates cell viability and stress tolerance. Proceedings of the National Academy of Sciences of the United States of America 106:6410-5. doi:10.1073/ pnas.0901940106

Hsieh, T.-H., Lee, J., Charng, Y. and Chan, M.-T. 2002. Tomato plants ectopically expressing Arabidopsis CBF1 show enhanced resistance 
to water deficit stress. Plant Physiology 130: 618-626. doi:10.1104/pp.006783

Hu, H., Dai, M., Yao, J., Xiao, B., Li, X., 2006. Overexpressing a NAM, ATAF, and CUC (NAC) transcription factor enhances drought resistance and salt tolerance in rice. Proceedings of the National Academy of Sciences 103:12987-12992.

Hu, H. and Xiong, L. 2014. Genetic engineering and breeding of drought-resistant crops. Annual Review of Plant Biology 65: 715-741. doi:10.1146/annurev-arplant-050213-040000

Huang, X.Y., Chao, D.Y., Gao, J.P., Zhu, M.Z., Shi, M. and Lin, H.X., 2009. A previously unknown zinc finger protein, DST, regulates drought and salt tolerance in rice via stomatal aperture control. Genes and Development 23:18051817. doi:10.1101/gad.1812409

Ijarotimi, O.S. and Ruth E.T. 2009. Comparison of nutritional composition and anti nutrient status of fermented, germinated and roasted bambara groundnut seeds (Vigna subterranea ). British Food Journal 111:376386.

Jaenicke, H. and Höschle-Zeledon, I. 2006. Strategic framework for underutilized plant species research and development, with special reference to Asia and the Pacific, and to sub-Saharan Africa, International Centre for underutilised crops, Colombo, Sri Lanka and global facilitation unit for underutilized species. Colombo and Global Facilitation Unit for underutilized species, Rome, Italy.

Jain, S. and Gupta, S. 2013. Biotechnology of neglected and underutilized crops. Springer Netherlands, Dordrecht.

Jang, I., Oh, S., Seo, J., Choi, W., Song, S.I., Kim, C.H., Kim, Y.S., Seo, H., Choi, Y. Do, Nahm, B.H. and Kim, J. 2003. Expression of a Bifunctional Fusion of the. Society 131:516524. doi:10.1104/pp.007237.which

Jeong, J.S., Kim, Y.S., Baek, K.H., Jung, H., Ha, S.H., Do Choi, Y., Kim, M., Reuzeau, C. and Kim, J.K. 2010. Root-specific expression of OsNAC10 improves drought tolerance and grain yield in rice under field drought conditions. Plant Physiology 153:185-197. doi:10.1104/pp.110.154773

Jeong, J.S., Kim, Y.S., Redillas, M.C.F.R., Jang, G., Jung, H., Bang, S.W., Choi, Y. Do, Ha, S.H.,
Reuzeau, C. and Kim, J.K. 2013. OsNAC5 overexpression enlarges root diameter in rice plants leading to enhanced drought tolerance and increased grain yield in the field. Plant Biotechnology Journal 11:101-114. doi:10.1111/pbi.12011

Jiang, S.-Y., Bhalla, R., Ramamoorthy, R., Luan, H.-F., Venkatesh, P.N., Cai, M. and Ramachandran, S. 2012. Over-expression of OSRIP18 increases drought and salt tolerance in transgenic rice plants. Transgenic Research 21: 785-95. doi:10.1007/s11248-011-9568-9

Kamphuis, L.G., Lichtenzveig, J., Oliver, R.P. and Ellwood, S.R. 2008. Two alternative recessive quantitative trait loci influence resistance to spring black stem and leaf spot in Medicago truncatula. BMC Plant Biology 8:30. doi:10.1186/1471-2229-8-30

Kang, J. 2002. Arabidopsis Basic Leucine Zipper Proteins That Mediate Stress-Responsive Abscisic Acid Signaling. Plant Cell Online 14:343-357.

Karaba, A., Dixit, S., Greco, R., Aharoni, A., Trijatmiko, K.R., Marsch-Martinez, N., Krishnan, A., Nataraja, K.N., Udayakumar, M. and Pereira, A. 2007. Improvement of water use efficiency in rice by expression of HARDY, an Arabidopsis drought and salt tolerance gene. Proceedings of the National Academy of Sciences of the United States of America 104:15270-5. doi:10.1073/ pnas.0707294104

Kasunga, M., Liu, Q., Miura, S., YamaguchiShinozaki, K. and Shinozaki, K. 1999. Improving plant drought, salt, and freezing tolerance by gene transfer of a single stressinducible transcription factor. Nature Biotechnology 17.

Kendabie, P., Jørgensen, S., Massawe, F., AzamAli, S. and Mayes, S. 2013. Day-length effects on growth and seed production efficiency in Bambara groundnut (Vigna subterranea L.). In: Hall, R., Rudebjer, P. and Padulosi, S. (Eds.). 3rd International Conference on Neglected and Underutilized Species: For a Food-Secure Africa, Accra, Ghana. pp. 7. Book of Abstract Rome: Bioversity International.

Khoury, C., Laliberté, B. and Guarino, L. 2010. Trends in ex situ conservation of plant genetic resources: A review of global crop and 
regional conservation strategies. Genetic Resources and Crop Evolution 57: 625-639. doi:10.1007/s10722-010-9534-z

Kooyers, N.J. 2015. The evolution of drought escape and avoidance in natural herbaceous populations. Plant Science 234:55-162. doi:10.1016/j.plantsci.2015.02.012

Li, H.-W., Zang, B.-S., Deng, X.-W. and Wang, X.-P., 2011. Overexpression of the trehalose6-phosphate synthase gene OsTPS1 enhances abiotic stress tolerance in rice. Planta 234 : 1007-18. doi:10.1007/s00425-0111458-0

Liu, F., Jensen, C. and Andersen, M. 2003. Hydraulic and chemical signals in the control of leaf expansion and stomatal conductance in soybean exposed to drought stress. Functional Plant Biology 30.

Liu, Q., Kasuga, M., Sakuma, Y., Abe, H., Miura, S., Yamaguchi-Shinozaki, K. and Shinozaki, K. 1998. Two transcription factors, DREB1 and DREB2, with an EREBP/AP2 DNA binding domain separate two cellular signal transduction pathways in drought- and lowtemperature-responsive gene expression, respectively, in Arabidopsis. Plant Cell 10: 1391-1406. doi: 10. 1105/ tpc. 10. 8. 1391

Lu, G., Gao, C., Zheng, X. and Han, B. 2008. Identification of OsbZIP72 as a positive regulator of ABA response and drought tolerance in rice. Planta 229:605-615.

Ludlow, M. 1989. Strategies of response to water stress. In: Structural and functional responses to environmental stresses: Water shortage. SPB Academic publishing, The Hague. pp. 269-282.

Mabhaudhi, T., Modi, a. T. and Beletse, Y.G. 2013. Growth, phenological and yield responses of a bambara groundnut (Vigna subterranea $\mathrm{L}$. Verdc) landrace to imposed water stress: IL. Rain shelter conditions. Water SA 39:191-198. doi:10.4314/wsa.v39i2.2

Manavalan, L.P., Chen, X., Clarke, J., Salmeron, J. and Nguyen, H.T. 2012. RNAi-mediated disruption of squalene synthase improves drought tolerance and yield in rice. Journal of Experimental Botany 63:163-175. doi:10.1093/jxb/err258

Mardis, E.R. 2008. The impact of next-generation sequencing technology on genetics. Trends
Genetics 24:133-41. doi:10.1016/j.tig. 2007.12.007

Massawe, F.J., Dickinson, M., Roberts, J. A. and Azam-Ali, S.N. 2002. Vigna subterranea (L.) Verdc) landraces revealed by AFLP markers. Genome 45, 1175-1180. doi:10.1139/g02-093

Massawe, F.J., Mwale, S.S., Roberts, J. A. 2005. Breeding in bambara groundnut (Vigna subterranea ( L.) Verdc .): Strategic considerations. African Journal of Biotechnology 4: 463-471. doi:10.5897/ AJB2005.000-3084

Mayes, S., Basu, S.M., Molosiwa, O., Redjeki, E.S., Ahmad, N.S., Khan, F., Zehra, S., Noah, S., Mayes, K., Roberts, J., Stadler, F., Massawe, F., Kilian, A. and Azam-Ali, S. 2013. Molecular analysis of Bambara groundnut, an underutilised African legume crop as Part of the BAMLINK Project - What Lessons Can We Learn? Proceedings of the 2nd International Symposim on Underutilized Plants Species "Crops Futur. - Beyond Food Security. pp. 451-458.

Mayes, S., Massawe, F.J., Alderson, P.G., Roberts, J.A., Azam-Ali, S.N. and Hermann, M. 2012. The potential for underutilized crops to improve security of food production. Journal of Experimental Botany 63:1075-1079. doi:10.1093/jxb/err396

Mazahib, A.M., Nuha, M.O., Salawa, I.S. and Babiker, E.E. 2013. Some nutritional attributes of bambara groundnut as influenced by domestic processing. International Food Research Journal 20: 1165-1171.

McCouch, S.R., Teytelman, L., Xu, Y., Lobos, K.B., Clare, K., Walton, M., Fu, B., Maghirang, R., Li, Z., Xing, Y., Zhang, Q., Kono, I., Yano, M., Fjellstrom, R., DeClerck, G., Schneider, D., Cartinhour, S., Ware, D. and Stein, L. 2002. Development and mapping of 2240 new SSR markers for rice (Oryza sativa L.). DNA Res. 9, 199-207. doi:10.1093/dnares/9.6.199

McKersie, B.D., Bowley, S.R., Harjanto, E. and Leprince, O. 1996. Water-deficit tolerance and field performance of transgenic Alfalfa overexpressing Superoxide Dismutase. Plant Physiology 111:1177-1181. doi:10.1104/ pp.111.4.1177

Menendez, C.M., Hall, A.E. and Gept, P. 1997. Genetic linkage map of cowpea (Vigna 
unguiculata) developed from a cross between twi inbred,domesticated lines. Theoretical and Applied Genetics 95:1210-1217.

Metzker, M.L. 2010. Sequencing technologies the next generation. Nature reviews. Genetics 11:31-46. doi:10.1038/nrg2626

Meuwissen, T.H.E., Hayes, B.J. and Goddard, M.E. 2001. Prediction of total genetic value using genome-wide dense marker maps. Genetics 157:1819-1829.

Mkandawire, C. 2007. Review of bambara groundnut (Vigna subterranea (L.) Verdc.) production in Sub-Sahara Africa. Agricultural Journal 2: 464-470.

Moe, K.T., Kwon, S.W. and Park, Y.J. 2012. Trends in genomics and molecular marker systems for the development of some underutilized crops. Genes and Genomics pp. 1-16. doi:10.1007/s13258-012-0049-1

Mohale, K.C., Belane, A.K. and Dakora, F.D. 2013. Symbiotic $\mathrm{N}$ nutrition, $\mathrm{C}$ assimilation, and plant water use efficiency in Bambara groundnut (Vigna subterranea L. Verdc) grown in farmers' fields in South Africa, measured using $15 \mathrm{~N}$ and $13 \mathrm{C}$ natural abundance. Biology and Fertility of Soils 50:307-319. doi:10.1007/s00374-013-0841-3

Molosiwa, O.O., Aliyu, S., Stadler, F., Mayes, K., Massawe, F., Kilian, A. and Mayes, S. 2015. SSR marker development, genetic diversity and population structure analysis of Bambara groundnut [Vigna subterranea (L.) Verdc.] landraces. Genetic Resources and Crop Evolution 62: 1225-1243. doi:10.1007/s10722015-0226-6

Morran, S., Eini, O., Pyvovarenko, T., Parent, B. and Singh, R. 2011. Improvement of stress tolerance of wheat and barley by modulation of expression of DREB/CBF factors. Plant Biotechnology Journal 9:230-249.

Morrell, P.L., Buckler, E.S. and Ross-Ibarra, J. 2011. Crop genomics: Advances and applications. Nature Reviews Genetics 13:8596. doi:10.1038/nrg3097

Muñoz-Amatriaín, M., Mirebrahim, H., Xu, P., Wanamaker, S.I., Luo, M., Alhakami, H., Alpert, M., Atokple, I., Batieno, B.J., Boukar, O., Bozdag, S., Cisse, N., Drabo, I., Ehlers, J.D., Farmer, A., Fatokun, C., Gu, Y.Q., Guo, Y.-N., Huynh, B.-L., Jackson, S.A., Kusi, F., Lawley,
C.T., Lucas, M.R., Ma, Y., Timko, M.P., Wu, J., You, F., Roberts, P.A., Lonardi, S. and Close, T.J. 2016. Genome resources for climateresilient cowpea, an essential crop for food security. doi:10.1101/059261

Murevanhema, Y.Y., Jideani, V. A. 2013. Potential of Bambara groundnut (Vigna subterranea (L.) Verdc) milk as a probiotic beverage-A review. Critical Reviews in Food Science and Nutrition 53:954-967. doi:10.1080/ 10408398.2011.574803

Nakashima, K., Tran, L.-S.P., Van Nguyen, D., Fujita, M., Maruyama, K., Todaka, D., Ito, Y., Hayashi, N., Shinozaki, K. and YamaguchiShinozaki, K. 2007. Functional analysis of a NAC-type transcription factor OsNAC6 involved in abiotic and biotic stressresponsive gene expression in rice. The Plant Journal 51:617-630. doi:10.1111/j.1365313X.2007.03168.x

National Drought Mitigation Center, Defining Drought: Overview.http://www.drought. unl.edu

Nelson, R.J., Naylor, R.L. and Jahn, M.M. 2004. The role of genomics research in improvement of "Orphan" Crops. Crop Science 44:1901. doi:10.2135/cropsci2004.1901

Ning, J., Li, X., Hicks, L.M. and Xiong, L. 2010. A Raf-like MAPKKK gene DSM1 mediates drought resistance through reactive oxygen species scavenging in rice. Plant Physiology 152: 876-890. doi:10.1104/pp.109.149856

Ning, Y., Jantasuriyarat, C., Zhao, Q., Zhang, H., Chen, S., Liu, J., Liu, L., Tang, S., Park, C.H., Wang, X., Liu, X., Dai, L., Xie, Q. and Wang, G.-L. 2011. The SINA E3 Ligase OsDIS1 negatively regulates drought response in rice. Plant Physiology 157:242-255. doi:10.1104/ pp.111.180893

NRC (National Research Council), 1996. Lost crops of Africa, National academy of press. Washington DC.

Oberschall, A., Deák, M., Török, K., Sass, L., Vass, I., Kovács, I., Fehér, A., Dudits, D. and Horváth, G.V. 2000. A novel aldose/aldehyde reductase protects transgenic plants against lipid peroxidation under chemical and drought stresses. Plant Journal 24:437-446. doi:10.1046/j.1365-313X.2000.00885.x 
Ocampo, E. and Robles, R. 2000. Drought tolerance in mungbean. I. Osmotic adjustment in drought stressed Mungbean. The Philippine Journal of Crop Science 25:1-5.

Oh, S., Kwon, C., Choi, D., Song, S. and Kim, J. 2007. Expression of barley HvCBF4 enhances tolerance to abiotic stress in transgenic rice. Plant Biotechnology Journal 5:646-656.

Okcu, G., Kaya, M. and Atak, M. 2005. Effects of salt and drought stresses on germination and seedling growth of pea (Pisum sativum L.). Turk J Agric 29:237-242.

Olaleye, A.A., Adeyeye, E.I. and Adesina, A.J. 2013. Chemical composition of bambara groundnut ( Vigna subterranea L. Verdc ). Seed Parts 48:167-178.

Olukolu, B. A., Mayes, S., Stadler, F., Ng, N.Q., Fawole, I., Dominique, D., Azam-Ali, S.N., Abbott, A.G. and Kole, C. 2012. Genetic diversity in Bambara groundnut (Vigna subterranea (L.) Verdc.) as revealed by phenotypic descriptors and DArT marker analysis. Genetic Resources and Crop Evolution 59:347-358. doi:10.1007/s10722011-9686-5

Orellana, S., Yañez, M., Espinoza, A., Verdugo, I., González, E., Ruiz-Lara, S., Casaretto, J. A. and 2010. The transcription factor SlAREB1 confers drought, salt stress tolerance and regulates biotic and abiotic stress-related genes in tomato. Plant, Cell Environment 33: 2191-2208. doi:10.1111/j.1365-3040.2010. 02220.x

Ouyang, S.-Q., Liu, Y.-F., Liu, P., Lei, G., He, S.-J., Ma, B., Zhang, W.-K., Zhang, J.-S. and Chen, S.-Y. 2010. Receptor-like kinase OsSIK1 improves drought and salt stress tolerance in rice (Oryza sativa) plants. Plant Journal 62:316-29. doi:10.1111/j.1365-313X.2010. 04146.x

Park, G.-G., Park, J.-J., Yoon, J., Yu, S.-N. and An, G., 2010. A RING finger E3 ligase gene, Oryza sativa Delayed Seed Germination 1 (OsDSG1), controls seed germination and stress responses in rice. Plant Molecular Biology 74:467-78. doi:10.1007/s11103-010-9687-3

Peleg, Z., Fahima, T., Krugman, T., Abbo, S., Yakir, D., Korol, A.B. and Saranga, Y. 2009. Genomic dissection of drought resistance in durum wheat $x$ wild emmer wheat recombinant inbreed line population. Plant, Cell and Environment 32:758-779. doi:10.1111/j.13653040.2009.01956.x

Pilon-Smits, E.A.H., Terry, N., Sears, T. and van Dun, K. 1999. Enhanced drought resistance in fructan-producing sugar beet. Plant Physiology and Biochemistry 37:313-317. doi:10.1016/S0981-9428(99)80030-8

Redillas, M., Jeong, J., Kim, Y., Jung, H. and Bang, S. 2012. The overexpression of OsNAC9 alters the root architecture of rice plants enhancing drought resistance and grain yield under field conditions. Plant Biotechnology Journal 10:792-805.

Saad, A.S.I., Li, X., Li, H.P., Huang, T., Gao, C.S., Guo, M.W., Cheng, W., Zhao, G.Y. and Liao, Y.C. 2013. A rice stress-responsive NAC gene enhances tolerance of transgenic wheat to drought and salt stresses. Plant Science 203204, 33-40. doi:10.1016/j.plantsci.2012.12.016

Saijo, Y., Hata, S., Kyozuka, J., Shimamoto, K. and Izui, K. 2000. Over-expression of a single $\mathrm{Ca}^{2+}$ dependent protein kinase confers both cold and salt/drought tolerance on rice plants. Plant Journal 23:319-327. doi:10.1046/j.1365313X.2000.00787.x

Schmutz, J., Cannon, S.B., Schlueter, J., Ma, J., Mitros, T., Nelson, W., Hyten, D.L., Song, Q., Thelen, J.J., Cheng, J., Xu, D., Hellsten, U., May, G.D., Yu, Y., Sakurai, T., Umezawa, T., Bhattacharyya, M.K., Sandhu, D., Valliyodan, B., Lindquist, E., Peto, M., Grant, D., Shu, S., Goodstein, D., Barry, K., Futrell-Griggs, M., Abernathy, B., Du, J., Tian, Z., Zhu, L., Gill, N., Joshi, T., Libault, M., Sethuraman, A., Zhang, X.-C., Shinozaki, K., Nguyen, H.T., Wing, R.A., Cregan, P., Specht, J., Grimwood, J., Rokhsar, D., Stacey, G., Shoemaker, R.C. and Jackson, S.A. 2010. Genome sequence of the palaeopolyploid soybean. Nature 463:178-83. doi:10.1038/nature08670

Schmutz, J., McClean, P.E., Mamidi, S., Wu, G.A., Cannon, S.B., Grimwood, J., Jenkins, J., Shu, S., Song, Q., Chavarro, C., Torres-Torres, M., Geffroy, V., Moghaddam, S.M., Gao, D., Abernathy, B., Barry, K., Blair, M., Brick, M.A, Chovatia, M., Gepts, P., Goodstein, D.M., Gonzales, M., Hellsten, U., Hyten, D.L., Jia, G., Kelly, J.D., Kudrna, D., Lee, R., Richard, 
M.M.S., Miklas, P.N., Osorno, J.M., Rodrigues, J., Thareau, V., Urrea, C. A., Wang, M., Yu, Y., Zhang, M., Wing, R.A., Cregan, P.B., Rokhsar, D.S. and Jackson, S. A. 2014. A reference genome for common bean and genome-wide analysis of dual domestications. Nature Genetics 46:707-13. doi:10. 1038/ng.3008

Schnable, P.S., Ware, D., Fulton, R.S., Stein, J.C., Wei, F., Pasternak, S., Liang, C., Zhang, J., Fulton, L., Graves, T.A., Minx, P., Reily, A.D., Courtney, L., Kruchowski, S.S., Tomlinson, C., Strong, C., Delehaunty, K., Fronick, C., Courtney, B., Rock, S.M., Belter, E., Du, F., Kim, K., Abbott, R.M., Cotton, M., Levy, A., Marchetto, P., Ochoa, K., Jackson, S.M., Gillam, B., Chen, W., Yan, L., Higginbotham, J., Cardenas, M., Waligorski, J., Applebaum, E., Phelps, L., Falcone, J., Kanchi, K., Thane, T., Scimone, A., Thane, N., Henke, J., Wang, T., Ruppert, J., Shah, N., Rotter, K., Hodges, J., Ingenthron, E., Cordes, M., Kohlberg, S., Sgro, J., Delgado, B., Mead, K., Chinwalla, A., Leonard, S., Crouse, K., Collura, K., Kudrna, D., Currie, J., He, R., Angelova, A., Rajasekar, S., Mueller, T., Lomeli, R., Scara, G., Ko, A., Delaney, K., Wissotski, M., Lopez, G., Campos, D., Braidotti, M., Ashley, E., Golser, W., Kim, H., Lee, S., Lin, J., Dujmic, Z., Kim, W., Talag, J., Zuccolo, A., Fan, C., Sebastian, A., Kramer, M., Spiegel, L., Nascimento, L., Zutavern, T., Miller, B., Ambroise, C., Muller, S., Spooner, W., Narechania, A., Ren, L., Wei, S., Kumari, S., Faga, B., Levy, M.J., McMahan, L., Van Buren, P., Vaughn, M.W., Ying, K., Yeh, C.-T., Emrich, S.J., Jia, Y., Kalyanaraman, A., Hsia, A.-P., Barbazuk, W.B., Baucom, R.S., Brutnell, T.P., Carpita, N.C., Chaparro, C., Chia, J.-M., Deragon, J.-M., Estill, J.C., Fu, Y., Jeddeloh, J.A., Han, Y., Lee, H., Li, P., Lisch, D.R., Liu, S., Liu, Z., Nagel, D.H., McCann, M.C., SanMiguel, P., Myers, A.M., Nettleton, D., Nguyen, J., Penning, B.W., Ponnala, L., Schneider, K.L., Schwartz, D.C., Sharma, A., Soderlund, C., Springer, N.M., Sun, Q., Wang, H., Waterman, M., Westerman, R., Wolfgruber, T.K., Yang, L., Yu, Y., Zhang, L., Zhou, S., Zhu, Q., Bennetzen, J.L., Dawe, R.K., Jiang, J., Jiang, N., Presting, G.G., Wessler, S.R., Aluru, S., Martienssen, R.A., Clifton, S.W.,
McCombie, W.R., Wing, R.A. and Wilson, R.K. 2009. The B73 maize genome: Complexity, diversity, and dynamics. Science 326:1112-5. doi:10.1126/science.1178534

Shashidhar, H., Kanbar, A., Toorchi, M., Raveendra, G. and Kundur, P. 2013. Breeding for drought resistance using whole plant architecture - Conventional and molecular approach. In: Andersen, S. (Ed.). Plant breeding from laboratories to Fields. Vienna, Austria.

Shen, H., Liu, C., Zhang, Y., Meng, X., Zhou, X., Chu, C. andWang, X. 2012. OsWRKY30 is activated by MAP kinases to confer drought tolerance in rice. Plant Molecular Biology 80:241-253. doi:10.1007/s11103-012-9941-y

Shendure, J. and Lieberman Aiden, E. 2012. The expanding scope of DNA sequencing. Nat. Biotechnol. 30:1084-94. doi:10.1038/nbt.2421

Sheveleva, E., Chmara, W., Bohnert, H.J. and Jensen, R.C. 1997. Increased salt and drought tolerance by D-Ononitol production in transgenic Nicotiana tabacum L. Plant Physiology 115:1211-1219.

Shin, D., Moon, S.-J., Han, S., Kim, B.-G., Park, S.R., Lee, S.-K., Yoon, H.-J., Lee, H.E., Kwon, H.-B., Baek, D., Yi, B.Y. and Byun, M.-O. 2011. Expression of StMYB1R-1, a novel potato single MYB-like domain transcription factor, increases drought tolerance. Plant Physiology 155: 421-432. doi:10.1104/ pp.110.163634

Shinozaki, K. and Yamaguchi-Shinozaki, K. 2006. Gene networks involved in drought stress response and tolerance. Journal of Experimental Botany 58:221-227. doi:10.1093/ jxb/erl164

Singh, P. 1991. Influence of water deficits on phenology, growth and dry matter allocation in chickpea (Cicer arietinum). Field Crops Research 28:1-15.

Singh, S., Teran, H. and Gutiérrez, J. 2001. Registration of SEA 5 and SEA 13 Drought Tolerant Dry Bean Germplasm. Crop Science 41.

Sledge, M., Ray, I. and Jiag, G. 2005. An expressed sequence tag SSR map of tetraploid alfalfa (Medicago sativa L.). Theor Appl Genet 111: 980-992. 
Song, Q.J., Marek, L.F., Shoemaker, R.C., Lark, K.G., Concibido, V.C., Delannay, X., Specht, J.E. and Cregan, P.B. 2004. A new integrated genetic linkage map of the soybean. Theoretische und angewandte Genetik 109:122-128. doi:10.1007/s00122-004-1602-3

Stadler, F. 2009. Analysis of differential gene expression under water-deficit stress and genetic diversity in bambara groundnut [Vigna subterranea ( L .) Verdc .] using novel high-throughput technologies. 177pp.

Subbarao, G., Chauhan, Y. and Johansen, C. 2000. Patterns of osmotic adjustments in pigeonpea - its importance as a mechanism of drought resistance. European Journal of Agronomy 12:239-249.

Sugano, S., Kaminaka, H., Rybka, Z., Catala, R., Salinas, J., Matsui, K., Ohme-Takagi, M. and Takatsuji, H. 2003. Stress-responsive zinc finger gene ZPT2-3 plays a role in drought tolerance in petunia. Plant Journal 36:830841. doi:10.1046/j.1365-313X.2003.01924.x

Sunkar, R., Bartels, D. and Kirch, H.-H. 2003. Overexpression of a stress-inducible aldehyde dehydrogenase gene from Arabidopsis thaliana in transgenic plants improves stress tolerance. Plant Journal 35:452-464. doi:10.1046/j.1365-313X.2003. 01819.x

Swamy, B.P.M. and Kumar, A. 2013. Genomicsbased precision breeding approaches to improve drought tolerance in rice. Biotechnology Advances 31:1308-18. doi:10.1016/j.biotechadv.2013.05.004

Tang, N., Zhang, H., Li, X., Xiao, J., Xiong, L., 2012. Constitutive activation of transcription factor OsbZIP46 improves drought tolerance in rice. Plant Physiology 158:1755-68. doi:10.1104/pp.111.190389

Teran, H. and Singh, S. 2002. Comparison of sources and lines selected for drought resistance in common bean. Crop Science 42.

Thoquet, P., Gherardi, M., Journet, E.P., Kereszt, A., Ané, J.-M., Prospéri, J.-M., Huguet, T., Ghérardi, M. and Prosperi, J.-M. 2002. The molecular genetic linkage map of the model legume Medicago truncatula: An essential tool for comparative legume genomics and the isolation of agronomically important genes. BMC Plant Biology 2:1. doi:10.1186/ 1471-2229-2-1

Thudi, M., Gaur, P.M., Krishnamurthy, L., Mir, R.R., Kudapa, H., Fikre, A., Kimurto, P., Tripathi, S., Soren, K.R., Mulwa, R., Bharadwaj, C., Datta, S., Chaturvedi, S.K. and Varshney, R.K. 2014. Genomics-assisted breeding for drought tolerance in chickpea. Functional Plant Biology 41: 1178-1190. doi:10.1071/FP13318

Varshney, R.K., Graner, A. and Sorrells, M.E. 2005. Genomics-assisted breeding for crop improvement. Trends in Plant Science 10:62130. doi:10.1016/j.tplants.2005.10.004

Vurayai, R., Emongor, V., Moseki, B., R. Vurayai, V. and Emongor, B.M. 2011. Physiological responses of Bambara groundnut (Vigna subterranea $\mathrm{L}$. Verdc) to short periods of water stress during different developmental stages. Asian Journal of Agricultural Sciences 3: 37-43.

Wang, Q., Guan, Y., Wu, Y., Chen, H., Chen, F. and Chu, C., n.d. Overexpression of a rice OsDREB1F gene increases salt, drought, and low temperature tolerance in both Arabidopsis and rice. Plant Molecular Biology 67: 589-602.

Ward, N. and Moreno-Hagelsieb, G., 2014. Quickly finding orthologs as reciprocal best hits with BLAT, LAST, and UBLAST: How much do we miss? PLoS One 9:1-6. doi:10.1371/ journal.pone.0101850

Wei, A., He, C., Li, B., Li, N. and Zhang, J. 2011. The pyramid of transgenes TsVP and BetA effectively enhances the drought tolerance of maize plants. Plant Biotechnology Journal 9: 216-229. doi:10.1111/j.1467-7652.2010. 00548.x

William, A., A, D.S., George, N., J, O.R.P., Olawale, O., Sean, M. and Aryo, F., R, A.H., 2016. Adoption of Bambara groundnut production and its effects on farmers ' welfare in Northern Ghana 11:583-594. doi:10.5897/AJAR2015. 10568

Williams, J.T. and Haq, N. 2002. Global research on underutilised crops an assessment of current activities and proposals.

Wu, X., Shiroto, Y., Kishitani, S., Ito, Y. and Toriyama, K. 2009. Enhanced heat and drought tolerance in transgenic rice seedlings 
overexpressing OsWRKY11 under the control of HSP101 promoter. Plant Cell Reports 28:21-30. doi:10.1007/s00299-0080614-x

Xiang, Y., Tang, N., Du, H., Ye, H. and Xiong, L. 2008. Characterization of OsbZIP23 as a key player of the basic Leucine Zipper Transcription Factor Family for Conferring Abscisic Acid Sensitivity and Salinity and Drought Tolerance in Rice. Plant Physiology 148: 1938-1952. doi:10.1104/pp.108.128199

Xiao, B., Huang, Y., Tang, N. and Xiong, L. 2007. Over-expression of a LEA gene in rice improves drought resistance under the field conditions. Theoretical and Applied Genetics 115: 35-46. doi:10.1007/s00122-0070538-9

Xiao, B.Z., Chen, X., Xiang, C. Bin, Tang, N., Zhang, Q.F. and Xiong, L.Z. 2009. Evaluation of seven function-known candidate genes for their effects on improving drought resistance of transgenic rice under field conditions. Molecular Plant 2: 73-83. doi:10.1093/mp/ ssn068

Xu, D.-Q., Huang, J., Guo, S.-Q., Yang, X., Bao, Y.-M., Tang, H.-J. and Zhang, H.-S. 2008. Overexpression of a TFIIIA-type zinc finger protein gene ZFP252 enhances drought and salt tolerance in rice (Oryza sativa L.). FEBS Letters 582:1037-1043. doi:10.1016/ j.febslet.2008.02.052

Xue, G.-P., Way, H.M., Richardson, T., Drenth, J., Joyce, P.A. and McIntyre, C.L. 2011. Overexpression of TaNAC69 leads to enhanced transcript levels of stress upregulated genes and dehydration tolerance in bread wheat. Molecular Plant 4:697-712. doi:10.1093/mp/ssr013

Yan, L., Fu, D., Li, C., Blechl, A., Tranquilli, G., Bonafede, M., Sanchez, A., Valarik, M., Yasuda, S. and Dubcovsky, J. 2006. The wheat and barley vernalization gene VRN3 is an orthologue of FT. Proceedings of the National Academy of Sciences of the United States of
America 103:19581-6. doi:10.1073/ pnas.0607142103

Yang, A., Dai, X. and Zhang, W.-H., 2012. A R2R3type MYB gene, OsMYB2, is involved in salt, cold, and dehydration tolerance in rice. Journal of Experimental Botany 63:25412556. doi:10.1093/jxb/err431

Yang, S., Gao, M., Xu, C., Gao, J., Deshpande, S., Lin, S., Roe, B.A. and Zhu, H. 2008. Alfalfa benefits from Medicago truncatula: the RCT1 gene from M. truncatula confers broadspectrum resistance to anthracnose in alfalfa. Proceedings of the National Academy of Sciences of the United States of America 105:12164-9. doi:10.1073/pnas.0802518105

You, J., Hu, H., Xiong, L., 2012. An ornithine äaminotransferase gene OsOAT confers drought and oxidative stress tolerance in rice. Plant Science 197:59-69. doi:10.1016/ j.plantsci.2012.09.002

Young, N.D. and Udvardi, M. 2009. Translating Medicago truncatula genomics to crop legumes. Curr. Opin. Plant Biology 12:193201. doi:10.1016/j.pbi.2008.11.005

Zhang, Y., Sledge, M. and Bouton, J. 2007. Genome mapping of white clover (Trifolium repens $\mathrm{L}$.) and comparative analysis within the Trifolieae using cross-species SSR markers. Theor Appl Genet 114:1367-1378.

Zhang, Z., Liu, X., Wang, X., Zhou, M., Zhou, X., Ye, X. and Wei, X. 2012. An R2R3 MYB transcription factor in wheat, TaPIMP1, mediates host resistance to Bipolaris sorokiniana and drought stresses through regulation of defense- and stress-related genes. New Phytologist 196:1155-1170. doi:10.1111/j.1469-8137.2012.04353.x

Zhu, B., Su, J., Chang, M., Verma, D.P.S., Fan, Y.L. and Wu, R. 1998. Overexpression of a Ä1pyrroline-5-carboxylate synthetase gene and analysis of tolerance to water- and salt-stress in transgenic rice. Plant Science 139:41-48. doi:10.1016/S0168-9452(98)00175-7 